\title{
21. INTERSTITIAL WATER STUDIES, LEG 35
}

\author{
Joris M. Gieskes, Scripps Institution of Oceanography, La Jolla, California \\ and \\ James R. Lawrence, Lamont-Doherty Geological Observatory, Palisades, New York
}

\begin{abstract}
Interstitial water analyses of samples collected during Leg 35 have revealed large concentration changes in the major dissolved constituents. Increases in calcium and decreases in magnesium appear to be related to the alteration of terrigenous debris in Plio-Pleistocene deposits, to the alteration of volcanic debris associated with chert zones, and, finally, to the low-temperature weathering of underlying basaltic rocks. Relatively large depletions in potassium can be related to similar processes, especially to the formation of authigenic feldspars and zeolites in the sediment column and of celadonite in the basalts. Depletions in dissolved sulfate are correlated with increases in ammonia and reflect bacterial sulfate reduction processes. High values of dissolved manganese reflect prevailing reducing conditions in the entire sediment column.

Measurements of electrical conductivities and porosities of the sediments are shown to yield reliable data on diffusion coefficients. This has been shown in particular by means of a profile of dissolved strontium at Site 323, for which a source is located in the high manganese content claystones, as well as in a 4-meter-thick nannochalk layer between 638 and 668 meters below the sediment-water interface.

Estimated diffusion coefficients are combined with present-day interstitial water concentration gradients in an analysis of possible fluxes of material through the sediment column.

Measurements of the $\mathrm{O}^{18} /{ }^{16}$ ratio show moderate to large decreases with depth. These changes can be related to diagenetic changes in both the sediment column and the underlying basalts.
\end{abstract}

\section{INTRODUCTION}

During most of the cruises of D/V Glomar Challenger of the Deep Sea Drilling Project, intensive studies have been carried out on the chemical composition of the interstitial waters. Most of the work done during Legs 1-23, particularly that on the major dissolved constituents, has recently been summarized by Manheim and Sayles (1974) and Sayles and Manheim (1975). Samples from selected sites of Legs 24, 25, 26, 28, 33, and 34 have been studied in the laboratory of one of us (JMG). Among the primary aims of these studies has been the detection and possible identification of diagenetic reactions occurring after burial, as well as the determination of the location where such reactions are most likely to occur (Gieskes, 1975). One problem has been that until recently very few studies have been carried out that have emphasized both the chemical composition of the interstitial waters and the chemistry and mineralogy of the solid phases (Gieskes et al., 1975; Perry et al., in preparation). From concentration changes in the interstitial waters, one can, of course, devise reaction schemes that can account for the observed changes (Sayles and Manheim, 1975), but the problem remains that such reaction schemes are somewhat ambiguous. Studies of the oxygen isotope composition of both interstitial waters and sediments, begun during Leg 15 (Lawrence, 1973), have shown that there are severe limits to the possible reactions occurring in the sediment column or, perhaps, in the underlying igneous rocks (Lawrence et al., 1975; Perry et al., in press).

Leg 35 was specifically planned to provide a very detailed geochemical study of samples collected in the Bellingshausen Sea area of the Southeast Pacific Ocean by interstitial water chemists, stable isotope chemists, clay mineralogists, and sedimentary geochemists. The sediments in this area are characterized by large contributions of continentally derived material, as well as ice-rafted debris. In such a complex system, it may be difficult to detect possible authigenic phases, but on the other hand, this may provide an opportunity to judge the relative influence of various reactions of continental and oceanic materials on the interstitial water chemistry. Notwithstanding the poor core recovery, it appears that representative samples were taken from the various lithologies, so that any conclusions contained in the present series of papers are not necessarily weakened by the relatively large sections of unsampled sediments.

This report deals with the study of both the physical properties (water contents, porosities, and electrical conductivities) and the chemical composition of the interstitial waters. The study of the physical properties, 
particularly of the electrical conductivity of the sediments, is pertinent to the problem of diffusion in the sediment-water system, as will be shown in the following section.

\section{SITE DESCRIPTION}

Two of the four sites drilled (Sites 322 and 323) reached igneous basement, whereas Site 324 was terminated after drilling to 220 meters and Site 325 had to be abandoned at some distance from basement, probably $0.14 \mathrm{sec}$ (Tucholke and Houtz, this volume).

All sediments in the upper portions of the holes, those of Miocene age and younger, are characterized by large terrigenous contributions. In the lower parts of Sites 322 and 323 , however, volcanogenic clays seem to be important contributors. In the terrigenous sections, Peters and Hollister (this volume) provide evidence of increased etching of clinopyroxenes with depth. Detailed descriptions of the sediments are found in the site reports, and in the specialized contributions to this volume.

Of interest in interstitial water studies are the rates of sedimentation (Gieskes, 1974, 1975, a, b; Sayles and Manheim, 1975). Pleistocene sedimentation rates (Figure 1) at Sites 322, 323, and 325 have been very similar (2-2.5 cm/1000 yr), whereas Pliocene rates were very high $(\sim 10 \mathrm{~cm} / 1000 \mathrm{yr})$, probably related to the rapid deposition of terrigenous debris during the glaciation of the Antarctic continent. In the older sediments, sedimentation rates were again appreciably slower. This is also reflected in a distinct change in clay mineralogy (Perry et al., this volume). The sediment column at Site 323 is characterized by a large sedimentation hiatus (boundary in Core 14) of about $35 \times 10^{6} \mathrm{yr}$. The thickness of the rapidly deposited Pliocene section is particularly pronounced at Sites 322 and 325 . These sites, of course, being closest to the Antarctic continent, receive larger amounts of turbidites.

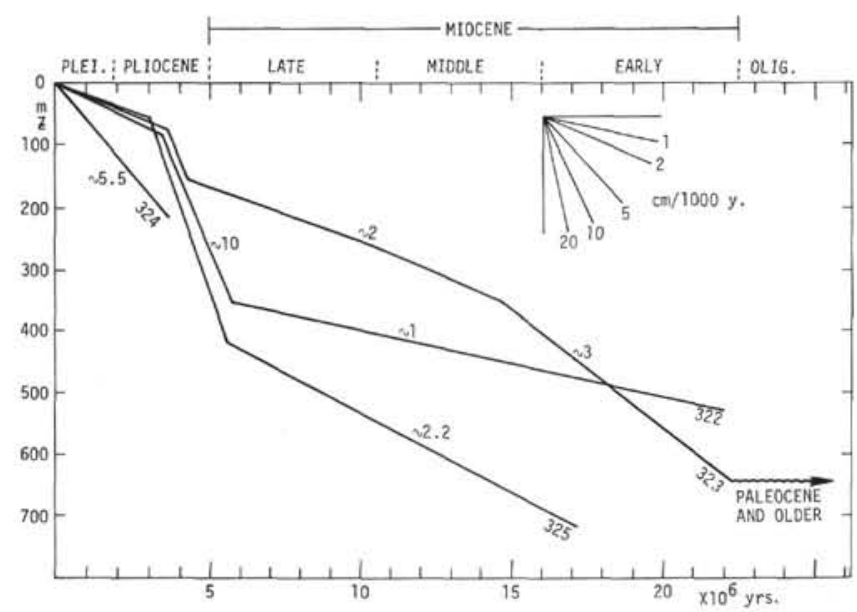

Figure 1. Ages and sedimentation rates, Sites 322, 323, 325.

\section{METHODS}

\section{Physical Properties}

Measurements of physical properties are reported and discussed by Tucholke and Edgar (this volume). Elec- trical conductivity measurements were carried out using a Schlumberger Mud Tester utilizing the same procedures as were described by Manheim and Waterman (1974). The apparatus was kindly lent to us by Dr. Frank Manheim. Porosities were measured using displacement volumes in water.

\section{Chemical Composition of Interstitial Waters}

Methods used were essentially the same as those described by Gieskes (1974, in press), with minor modifications.

Onboard-ship analyses were made of salinity (refractometer), alkalinity (potentiometric titration), $p \mathrm{H}$, $\mathrm{Ca}^{++}, \mathrm{Mg}^{++}$, dissolved silica, and ammonia. The remainder of the measurements were carried out in the home laboratory, using the samples that were titrated for alkalinity onboard ship. Acid storage has the advantage of maintaining easily oxidizable cations, e.g., $\mathrm{Mn}^{++}$, in solution.

Accuracies are generally the same as those presented by Gieskes (1974). However, sometimes only very minor quantities of interstitial water were recovered. Some of these samples (Site 322) appear to have been affected by some residual moisture in the squeezing apparatus. After this was discovered, all apparatus was dried with acetone to ensure absolute dryness. Generally, however, data quality appears to be acceptable.

Recent investigations, spurred by "negative" magnesium values obtained onboard ship, have indicated that the calcium determination using the method of Gieskes (1974) is very slightly dependent on the $\mathrm{Mg} / \mathrm{Ca}$ ratio in the solution. Using the EDTA method (Gieskes, 1974) for total alkaline earths $\left(D_{t}\right)$ and the EGTA method (Gieskes, 1974) for calcium, standardized with IAPSO standard sea water $\left(\mathrm{Ca}_{t}\right)$, we can compute over the range of $\mathrm{Mg} / \mathrm{Ca}$ ratios commonly found in interstitial waters $(0-8)$ :

$$
\begin{aligned}
& \mathrm{Mg}=\left(\mathrm{D}_{t}-0.9558 \mathrm{Ca}_{t}\right) / 1.0087 \\
& \mathrm{Ca}=0.9558 \mathrm{Ca}_{t}+0.0087 \mathrm{Mg}
\end{aligned}
$$

Data obtained agree very well with data obtained by atomic absorption methods.

Analyses of the $\mathrm{O}^{18} / \mathrm{O}^{16}$ ratio of the interstitial waters were carried out in duplicate, using the $\mathrm{CO}_{2}$ equilibration method of Epstein and Mayeda (1953).

\section{RESULTS AND DISCUSSION}

\section{Physical Properties}

Data for water contents, porosities, and formation factors are presented in Table 1 and Figures 5, 12, 20, and 26 . Only those water contents that were measured in conjunction with the formation factor measurements are presented here. For a more detailed discussion of the significance of the porosity data, see Tucholke et al. (this volume). We emphasize the essential correctness of the method of Manheim and Waterman (1974) in their estimation of the sediment porosity. All data in Table I show agreement between calculated and 
TABLE

Water Contents, Porosities, and Formation Factors

\begin{tabular}{|c|c|c|c|c|c|}
\hline \multirow[b]{2}{*}{$\begin{array}{c}\text { Sample } \\
\text { (Interval in } \mathrm{cm} \text { ) }\end{array}$} & \multirow[b]{2}{*}{$\% \mathrm{H}_{2} \mathrm{O}$} & \multicolumn{2}{|c|}{$\%$ Porosity } & \multirow[b]{2}{*}{$\begin{array}{c}\text { Formation } \\
\text { Factor }\end{array}$} & \multirow[b]{2}{*}{ Remarks } \\
\hline & & $\begin{array}{l}\text { Calcu- } \\
\text { lated }\end{array}$ & $\begin{array}{l}\text { Meas- } \\
\text { ured }\end{array}$ & & \\
\hline \multicolumn{6}{|l|}{ Site 322} \\
\hline $1-1,0-15$ & 47 & 71 & & & \\
\hline $1-2,140-150$ & & & & 3.45 & \\
\hline $2-2,110-115$ & 45 & 70 & & & \\
\hline $2-2,140-150$ & 24 & 46 & & 3.6 & Dubious \\
\hline $3-1,30-40$ & 47 & 71 & & 3.9 & \\
\hline $4-2,15-30$ & & & & 6.9 & \\
\hline $42,22-24$ & 33 & 58 & & & \\
\hline $5-1,136-140$ & 27 & 50 & & & \\
\hline $9-2,139-142$ & 24 & 46 & & & \\
\hline $10-1,46-48$ & 22 & 43 & & & \\
\hline $10-1,1-5-107$ & 22 & 43 & & & \\
\hline $11-2,51-52$ & 18 & 37 & & & \\
\hline $11-4,45-48$ & & & & 8.0 & Sandstone \\
\hline $11-4,124-125$ & 23 & 45 & & & \\
\hline $11-6,57-59$ & 23 & 45 & & & \\
\hline $11-6,93-98$ & & & & 17.8 & Claystone \\
\hline \multicolumn{6}{|l|}{ Site 323} \\
\hline $1-3,37-40$ & & & & 2.7 & Sand \\
\hline $1-5,43-48$ & & & & 2.2 & Disturbed clay \\
\hline $1, \mathrm{CC}$ & & & & 2.6 & Loose mud \\
\hline $2-1,79-81$ & 56 & 78 & 74 & & \\
\hline $2-1,106-108$ & 43 & 67 & 71 & & \\
\hline $3-1,106-107$ & 33 & 58 & 59 & & \\
\hline $3-2,73-74$ & 51 & 74 & & & \\
\hline $3-2,103-107$ & & & & 3.2 & Slightly disturbed \\
\hline $4-1,102-104$ & 48 & 72 & 73 & & \\
\hline $5-1,141$ & 33 & 58 & 62 & & \\
\hline $5, \mathrm{CC}$ & 31 & 55 & 56 & & \\
\hline $6-1,140$ & 40 & 64 & 64 & & \\
\hline $6, \mathrm{CC}$ & 42 & 66 & 65 & & \\
\hline $7-1,140$ & 41 & 65 & 63 & & \\
\hline $7-2,101-104$ & & & & 5.9 & \\
\hline $7-2,113$ & 37 & 61 & 61 & & \\
\hline $8-1,106$ & 29 & 52 & 52 & & \\
\hline $8-1,144$ & 29 & 52 & 51 & & \\
\hline $9-2,100$ & 26 & 49 & 48 & & \\
\hline $10-1,40$ & & & & 8.4 & \\
\hline $10-1,130-134$ & & & & 9.6 & \\
\hline $10-1,142$ & 24 & 46 & 47 & & \\
\hline $11-1,52$ & & & & 7.3 & \\
\hline $11-1,67$ & 26 & 49 & 48 & & \\
\hline $11-1,84-88$ & & & & 7.0 & \\
\hline $12-1,101$ & 15 & 32 & 29 & & \\
\hline $12-2,45$ & 21 & 42 & 40 & & \\
\hline $12-2,120-124$ & & & & 8.7 & \\
\hline $13-5,130-136$ & & & & 12.7 & \\
\hline $13-5,140$ & 20 & 41 & 41 & & \\
\hline $13-5,145$ & 21 & 42 & 43 & & \\
\hline $13-6,138$ & 18 & & 36 & & \\
\hline $14-2,14-17$ & & & & 11.9 & \\
\hline $14-2,34$ & (14) & (30) & (30) & & \\
\hline $14-2,57-60$ & & & & 13.9 & \\
\hline $14, \mathrm{CC}$ & 25 & 47 & 51 & & \\
\hline $15-1,79$ & 27 & 50 & 50 & & \\
\hline $15-5,48$ & 28 & 51 & 52 & & \\
\hline $16-1,31$ & 19 & 39 & 41 & & \\
\hline $16-2,63-65$ & 20 & 40 & 41 & & \\
\hline $16-4,143-144$ & 24 & 46 & 46 & & \\
\hline $17-6,143-144$ & 25 & 47 & 47 & & \\
\hline $18-3,19-21$ & 23 & 43 & 47 & & \\
\hline $18-4,37$ & 24 & 46 & 45 & & \\
\hline $18-4,75-77$ & 26 & 49 & 48 & & \\
\hline
\end{tabular}


TABLE 1-Continued

\begin{tabular}{|c|c|c|c|c|c|}
\hline \multirow[b]{2}{*}{$\begin{array}{c}\text { Sample } \\
\text { (Interval in } \mathrm{cm} \text { ) }\end{array}$} & \multirow[b]{2}{*}{$\% \mathrm{H}_{2} \mathrm{O}$} & \multicolumn{2}{|c|}{ \% Porosity } & \multirow[b]{2}{*}{$\begin{array}{l}\text { Formation } \\
\text { Factor }\end{array}$} & \multirow[b]{2}{*}{ Remarks } \\
\hline & & $\begin{array}{l}\text { Calcu- } \\
\text { lated }\end{array}$ & $\begin{array}{l}\text { Meas- } \\
\text { ured }\end{array}$ & & \\
\hline $18-5,124-126$ & 24 & 46 & 47 & & \\
\hline \multicolumn{6}{|l|}{ Site 324} \\
\hline $\begin{array}{l}1-3,104-107 \\
1-4,107-110 \\
1-6,123-127 \\
2-1,112-115 \\
2-2,77-80 \\
2-3,105-108 \\
2-4,123-125 \\
2-6,98-101 \\
3-1,112-115 \\
3-4,50-53 \\
4-3,35-38 \\
4-4,85-88 \\
4-5,82-85 \\
4-6,129-132 \\
5-3,55 \\
6-6,139 \\
7-1,71 \\
7-4,124 \\
8-2,132 \\
8-3,101\end{array}$ & & & & $\begin{array}{l}2.8 \\
2.9 \\
3.1 \\
3.7 \\
3.5 \\
4.3 \\
4.1 \\
3.3 \\
4.3 \\
5.1 \\
3.6 \\
4.3 \\
(2.6) \\
5.0 \\
4.0 \\
3.7 \\
4.4 \\
4.4 \\
5.1 \\
5.7\end{array}$ & $\begin{array}{c}\text { Soft } \\
\text { Soft and disturbed } \\
\text { Soft } \\
\text { Sticky, disturbed } \\
\text { Sticky, disturbed } \\
\text { Sticky, disturbed } \\
\text { Sticky, disturbed }\end{array}$ \\
\hline \multicolumn{6}{|l|}{ Site 325} \\
\hline $\begin{array}{l}1-1,125 \\
2-2,38 \\
3-2,71 \\
4-2,30 \\
5-1,90-94 \\
5-1,118 \\
5-1,123-128 \\
6-1,138 \\
7-2,88 \\
7-2,119 \\
8-1,84-86 \\
8-1,129 \\
8-1,133\end{array}$ & $\begin{array}{l}33 \\
30 \\
29 \\
24 \\
32 \\
21\end{array}$ & $\begin{array}{l}58 \\
54 \\
52 \\
46 \\
56 \\
42\end{array}$ & $\begin{array}{l}56 \\
53 \\
52 \\
45 \\
54 \\
41 \\
\\
41\end{array}$ & $\begin{array}{l}2.3 \\
5.4 \\
5.9\end{array}$ & $\begin{array}{l}\text { Disturbed } \\
\text { Disturbed } \\
\text { Disturbed }\end{array}$ \\
\hline
\end{tabular}

measured porosities within the precision of the measurements $( \pm 3 \%)$.

The formation factor $(F)$ is obtained from the ratio of the specific resistivity of the sediment to that of the extruded interstitial water. This formation factor can be related to the diffusivities of ions in the sediments vis-avis that in the pure interstitial solution, using the analogy between ionic mobilities and diffusivities (Manheim and Waterman, 1974; Turk, 1976). This leads to

$$
D_{i}=\frac{D_{o}}{p F}
$$

where $D_{i}=$ coefficient of interstitial water in diffusion/sediment

$D_{o}=$ coefficient of pure interstitial diffusion/water

$p=$ porosity

$F=$ formation factor

Turk (1976) has shown that even in a montmorillonite matrix the resistivity of the sediment is essentially determined by that of the interstitial waters, and not by the solid matrix, at salt concentrations of ionic strengths equal to that of seawater. Manheim (1970) and Manheim and Waterman (1974) discuss the relationship between $F$ and $p$ in terms of the so-called Archie (1942) relationship:

$$
F=p^{-n}
$$

where $n$ is a coefficient characteristic for the sediment matrix.

Atkins and Smith (1961) show that for sediments with a mixed matrix the Archie relationship changes into

$$
F=a p^{-n}
$$

where $a$ is a constant. This leads to the expression

$$
\log F=n \log p+\log a
$$

so that one expects, in sediments with reasonably homogeneous lithologies, a linear relationship between $\log F$ and $\log p$. In Figure 2, the data for $F$ and $p$ obtained at Sites 322 and 323 are plotted. In general, the relationship suggested by Equation 4 is fulfilled for Site 


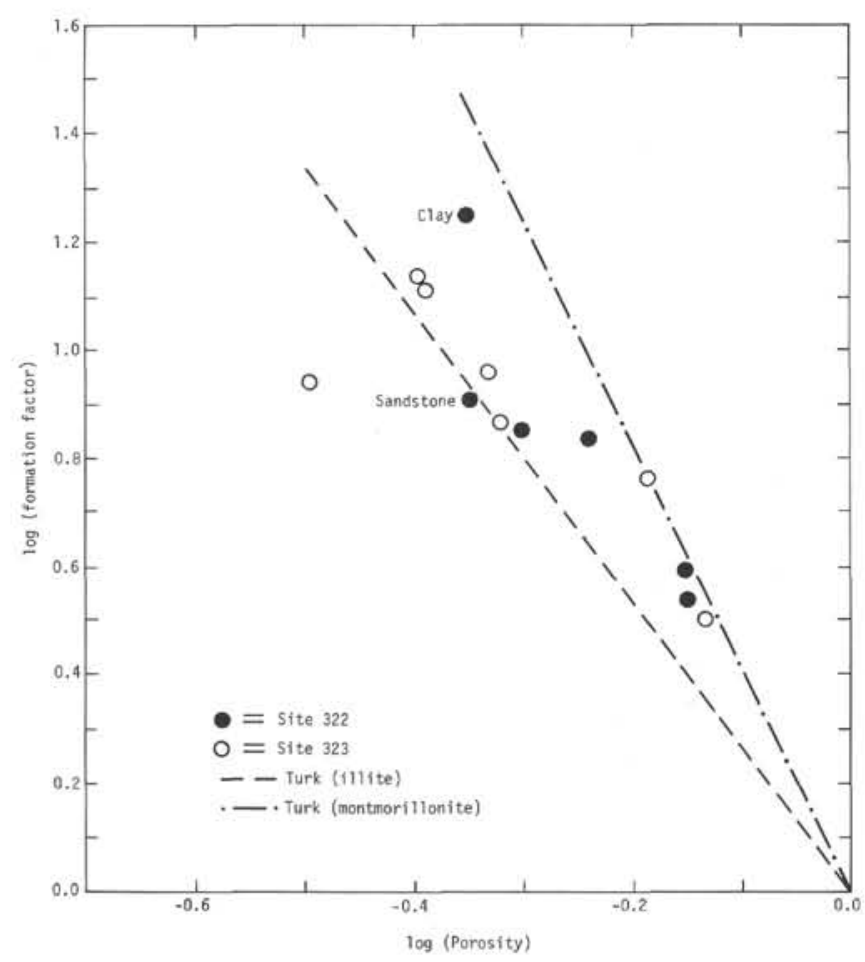

Figure 2. Log F versus $\log p$, Sites 322 and 323.

322 , with one or two exceptions due to measurements in very different lithologies. For Site 323 , the scatter is much larger, but again, very different lithologies occur. In addition, the relationships for illite and montmorillonite (Turk, 1976) are given in Figure 2. Typically, most of the measured values are bracketed by these data, a fact to be expected from the general lithology of the sediments (Zemmels and Cook, this volume).

The profile of dissolved strontium (Figure 3 ) for Site 323 yields a unique opportunity to test the validity of diffusion coefficients obtained by this technique. At 640 meters, several layers $(\sim 4 \mathrm{~m})$ of nannofossil chalks of Danian age were recovered. These were the only layers in the entire hole containing abundant calcium carbonate. Recrystallization of this calcareous material has led to an increase in dissolved strontium, which diffuses upward in the column. In addition, the ferruginous claystones between 638 and 668 meters (Drever, this volume) are enriched in strontium, possibly associated with manganese oxides. Possible dissolution of this material (high $\mathrm{Mn}^{++}$, Table 2) might also release $\mathrm{Sr}^{++}$to the interstitial waters.

By inspection of the values of the formation factors (Figure 12) and of the porosities (Figures 3 and 12) and allowing for a temperature gradient of $4^{\circ} \mathrm{C} / 100 \mathrm{~m}$, one calculates from Equation 1 and the data for $D_{o}(\mathrm{Li}$ and Gregory, 1974) a value of $D_{i}=2.4 \times 10^{-6} \mathrm{~cm}^{2} / \mathrm{sec}$ at about 250 meters and of $D_{i}=2.0 \times 10^{-6} \mathrm{~cm}^{2} / \mathrm{sec}$ at about 500 meters. The sediments overlying the chalks are of Oligocene age or younger and have accumulated at rates of $2-3 \mathrm{~cm} / 1000 \mathrm{yr}$ between 650 and 200 meters. Using a sedimentation rate $(u)$ of $2.5 \mathrm{~cm} / 1000 \mathrm{yr}$, one can calculate a so-called "communication depth" (Gieskes, 1975) or "scale height" (Lerman, 1975) Z* from the relationship

$$
Z^{*}=\frac{D_{i}}{u}
$$

For a diffusion coefficient $D_{i}=2.0 \times 10^{-6} \mathrm{~cm}^{2} / \mathrm{sec}$, one obtains a value of $Z^{*}=250$ meters, so that one expects a steady-state gradient of dissolved strontium to a sediment depth of about 450 meters (cf., Figure 3). For a diffusion coefficient of $D_{i}=1 \times 10^{-6} \mathrm{~cm}^{2} / \mathrm{sec}$, the steady-state strontium gradient should not extend to more than 125 meters above the chalk horizon. Clearly this is not the case.

The flux of dissolved strontium through the sediment column can be obtained from the relationship

$$
J_{t}=-p D_{i} \frac{\delta C_{S}}{\delta z}
$$

where $J_{t}=$ flux through $1 \mathrm{~cm}^{2}$ of sediment

$$
C_{S}=\text { concentration per unit volume of in- }
$$
terstitial water phase

This equation can be rewritten by introducing Equation 1:

$$
J_{t}=-\frac{D_{o}}{F} \frac{\delta C_{S}}{\delta z}
$$

In this equation, of course, one must consider $D_{o}$ at the in situ temperature. Taking $D_{o}$ at the sediment surface

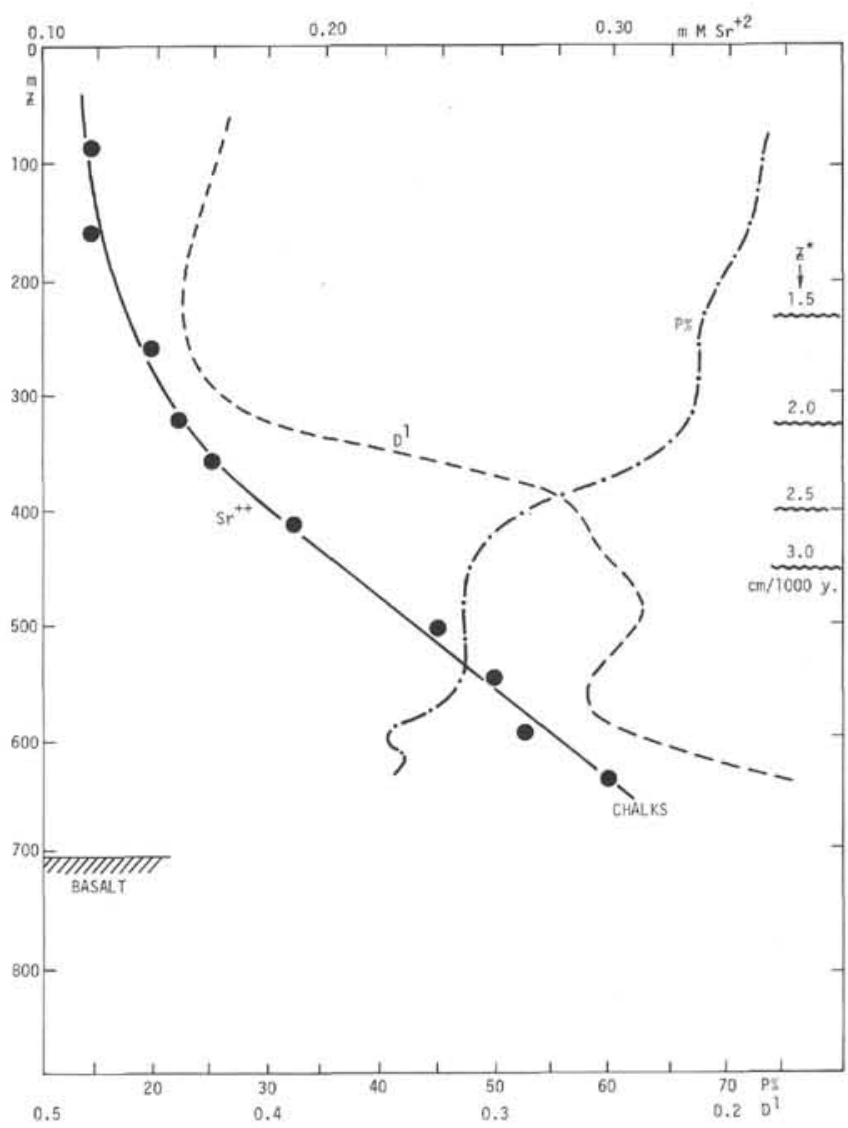

Figure 3. Porosities (p), diffusion factors ( $\left.\mathrm{D}^{\prime}\right)$, and strontium gradients, Site 323. 
(about $0^{\circ} \mathrm{C}$ ) as a reference value, we can correct $(1 / F)$ for temperature using a temperature coefficient of about 2.1 times for a rise of $25^{\circ} \mathrm{C}$ ( $\mathrm{Li}$ and Gregory, 1974). This corrected $(1 / F)$ value is designated by the symbol $D^{\prime}$ in Figures 3 and 4 , and we will call this the sediment diffusion factor. If $D^{\prime}$ is constant with depth, the slope of a concentration depth profile must be linear if a steadystate flux is to be maintained. From Figure 3 it is apparent that below 450 meters, i.e., within the range of $Z^{*}$, a linear gradient in dissolved strontium occurs. Above this, increased curvature is due to both the larger $D_{o} / F$ values and the influence of the sedimentation rate. The shape of the strontium profile is essentially a result of physical processes and appears not to be influenced by reactions in the sediment column above $\sim 640-650$ meters.

The above evidence suggests that formation factor data can be usefully applied in the estimation of sediment diffusion coefficients. The information obtained on the nature of the dissolved strontium gradient is of importance in the discussion of gradients of other chemical parameters at Site 323.

Figure 4 presents data for the sediment diffusion factor $D^{\prime}$ and for porosity for Site 322, where an analogy with a "point" source such as was made at Site 323 cannot be made.

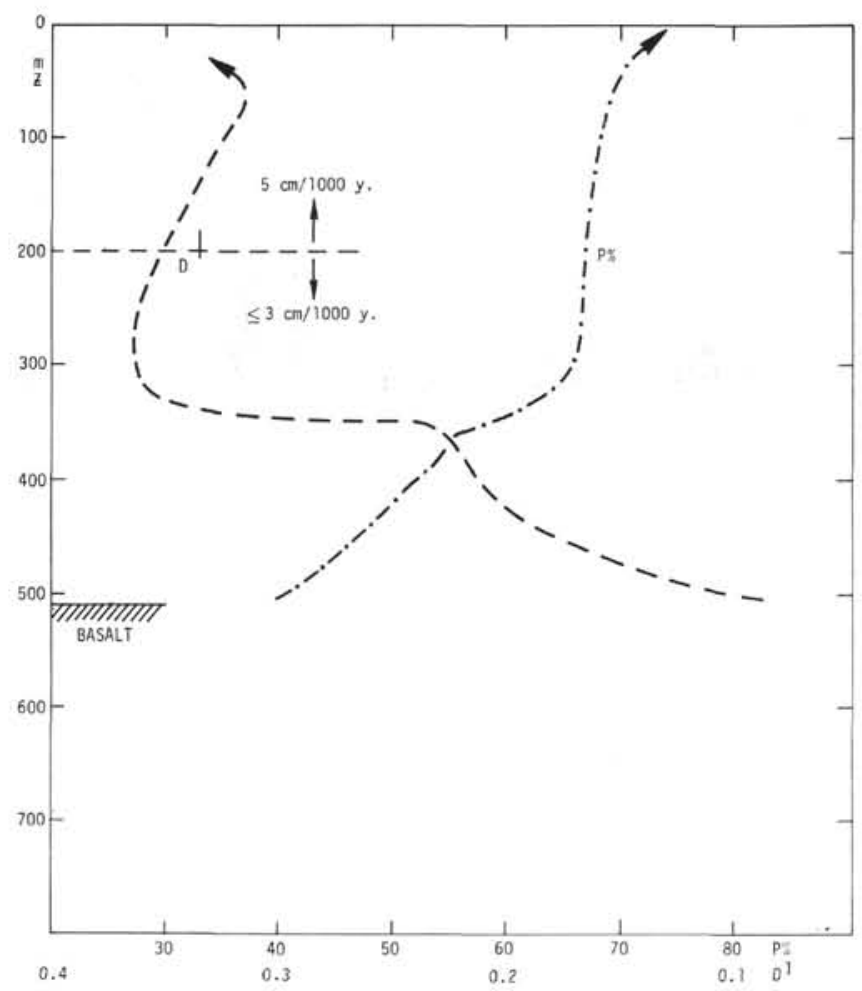

Figure 4. Porosities (p) and diffusion factors (D') Site 322.

\section{CHEMICAL COMPOSITION OF INTERSTITIAL WATERS}

In this section, the various observations made at each site will be discussed briefly. More general deductions will be presented in a subsequent section.
Site 322

Data presented in Table 2 indicate that at this site little sulfate reduction occurs. The largest depletion (only about 3-4 mmoles $\mathrm{SO}_{4} / 1$ ) occurs at about 200 meters and is reflected in a maximum in dissolved ammonia (Figure 7). Data for dissolved manganese suggest prevailing reducing conditions throughout the hole (Table 2). In addition, alkalinity values (Figure 6) show a very slight maximum in the upper part of the sediment column. Below 300 meters, however, alkalinity values show a gradual decrease towards basalt basement.

Dissolved calcium and magnesium (Figure 8) show somewhat complicated profiles which indicate a very rapid increase in dissolved $\mathrm{Ca}^{++}(\sim 6 \mathrm{mmoles} / 1)$ and decrease in $\mathrm{Mg}^{++}(\sim 10 \mathrm{mmoles} / 1)$ in the first 100 meters. Then, to a depth of 350 meters, i.e., at the base of the rapidly deposited Pliocene section, little change occurs, but, below this, sharp increases in $\mathrm{Ca}^{++}$and decreases in $\mathrm{Mg}^{++}$(below $430 \mathrm{~m}$ ) are observed. Figure 9 suggests a correlation between changes in $\mathrm{Ca}^{++}$and $\mathrm{Mg}^{++}$, with a ratio $\Delta \mathrm{Ca}^{++} / \Delta \mathrm{Mg}^{++}$of about 1.5. Consideration of the $\mathrm{Ca}^{++}$gradients at 475 and 300 meters suggests a slope ratio of about $3.2 \pm 0.2$, whereas the factor $D^{\prime}$ (Figure 4) suggests a ratio of $2.4 \pm 0.2$ It is possible that a steady-state situation does not actually exist. Also, the profile of dissolved $\mathrm{Ca}^{++}$may be complicated by the precipitation of $\mathrm{CaCO}_{3}$ in the sediment column; typically, some "recrystallized" carbonate was observed (see site reports). The amounts involved, however, must be rather small, as only small decreases in alkalinity are observed and these changes are probably largely due to diffusion of $\mathrm{HCO}_{3}-$ into the basalts. The depth profiles

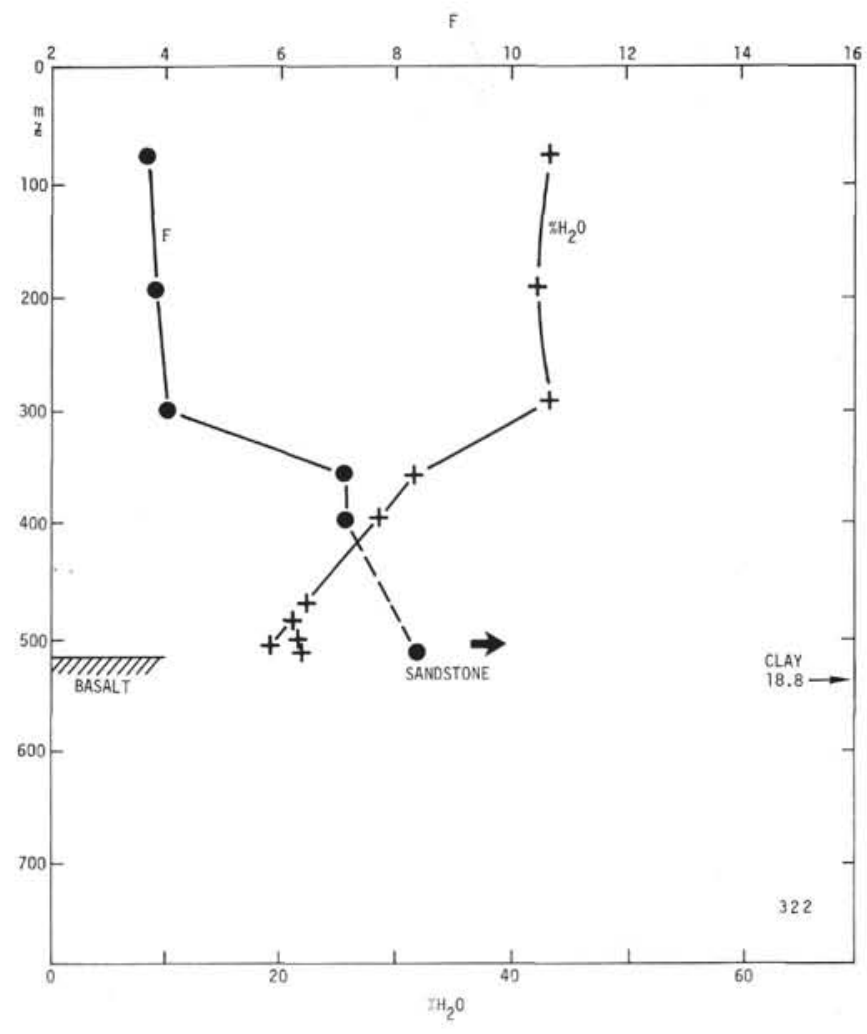

Figure 5. Formation factor (F) and water content, Site 322. 
TABLE 2

Interstitial Water Data, Leg 35

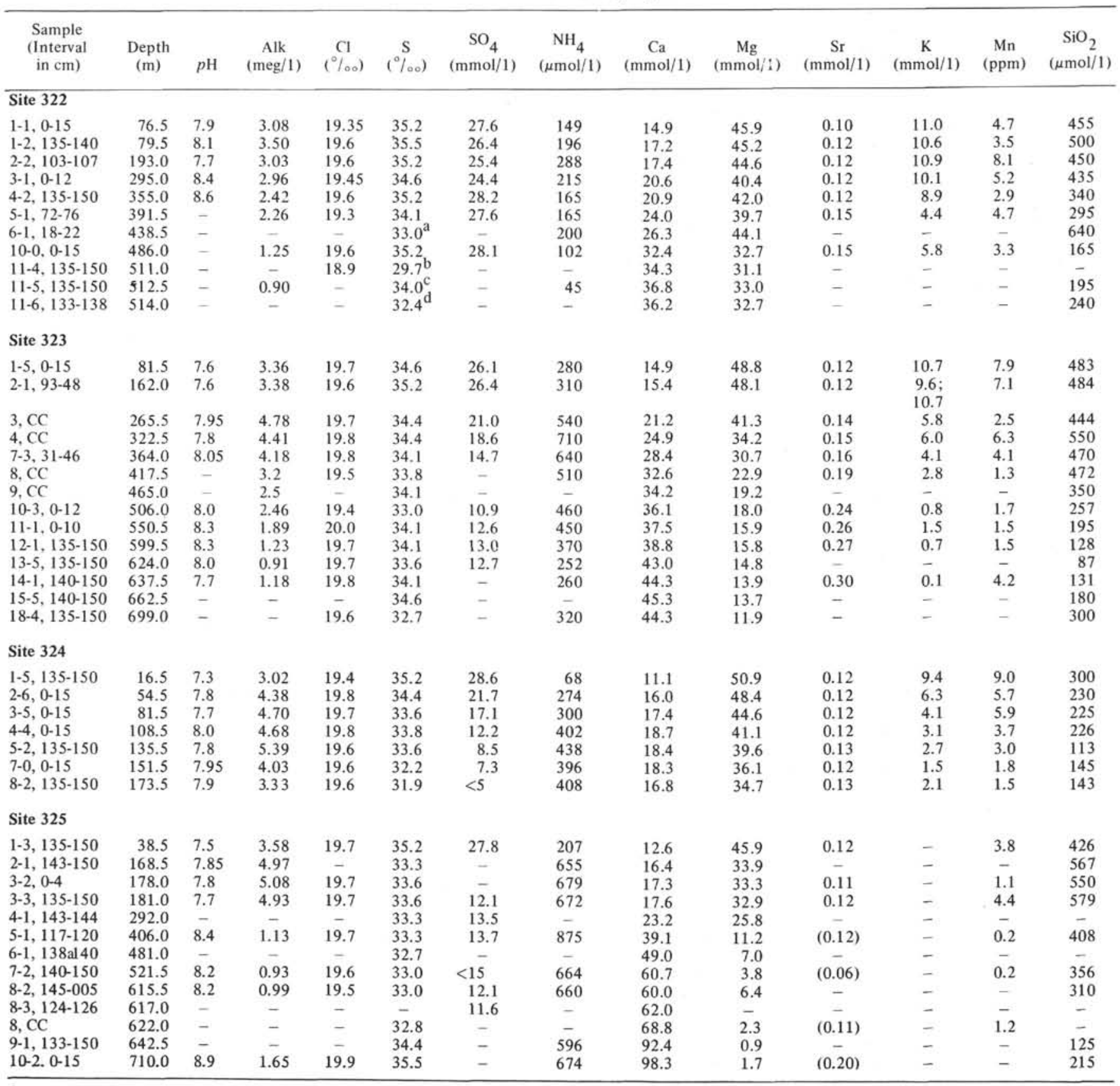

${ }^{a}$ Distilled water contamination; data corrected (7\%).

${ }^{b}$ Distilled water contamination; data corrected (18\%).

${ }^{\mathrm{c}}$ Distilled water contamination; data corrected (3\%).

${ }^{d}$ Distilled water contamination; data corrected ( $9 \%$ ).

of $\mathrm{Ca}^{++}$and $\mathrm{Mg}^{++}$, therefore, suggest the presence of two or three main reaction zones:

1) In the upper 100-200 meters of sediments, changes in $\mathrm{Ca}^{++}$and $\mathrm{Mg}^{++}$may be related to alteration of terrigenous material (Peters and Hollister, this volume).

2) In the lower, volcanogenic portion of the sediments, i.e., below 438 meters (cf., Perry et al., this volume), weathering reactions of igneous materials occur.
3) Typically, the basalts underlying Site 322 were found to be altered due to weathering reactions. Uptake of $\mathrm{Mg}^{++}$into these basalts from the pore fluids may be disputed, but low-temperature weathering reactions of basaltic materials at Site 245 (Gieskes et al., 1975) do suggest significant uptake of $\mathrm{Mg}^{++}$and release of $\mathrm{Ca}^{++}$.

Dissolved silica values above 400 meters may reflect the presence of small amounts of opaline silica (diatoms), as is also suggested by the data obtained by 


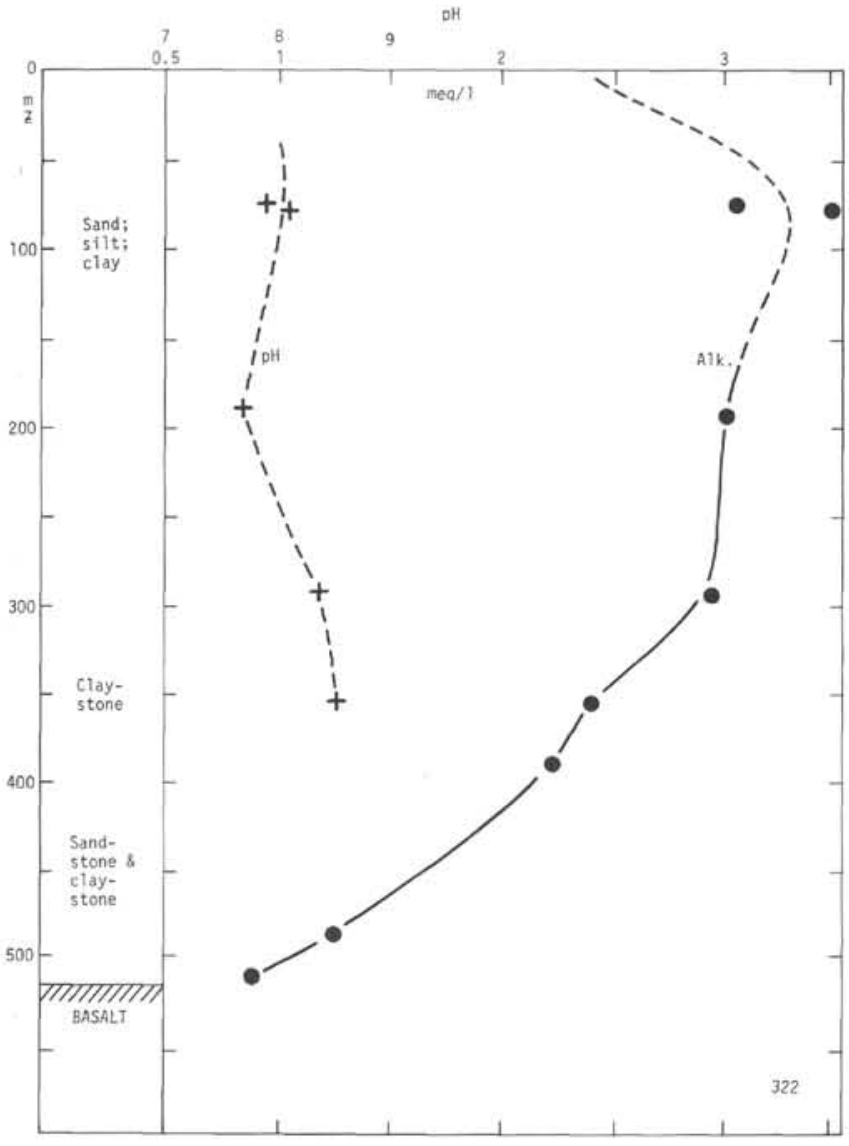

Figure 6. Lithology, $p H\left(25^{\circ} \mathrm{C}\right)$, and alkalinity, Site 322 .

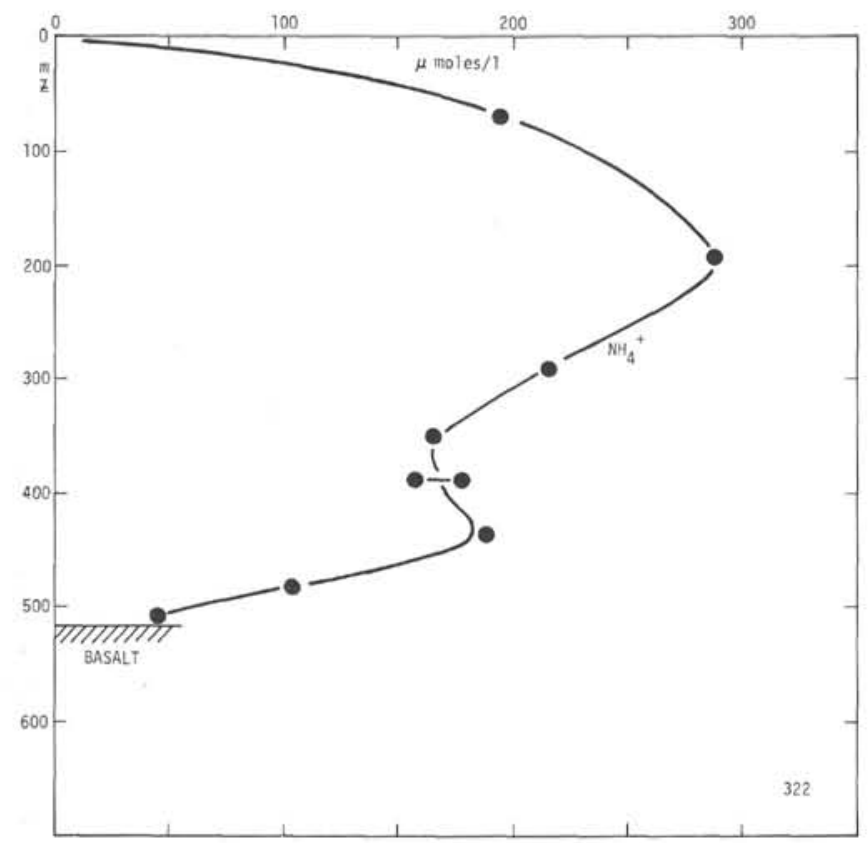

Figure 7. Ammonia, Site 322.

the Russian investigators (Bogdanov et al., this volume). The much lower values in the bottom section of the hole reflect the very different lithology (cf., Perry et al., this volume; Zemmels and Cook, this volume).

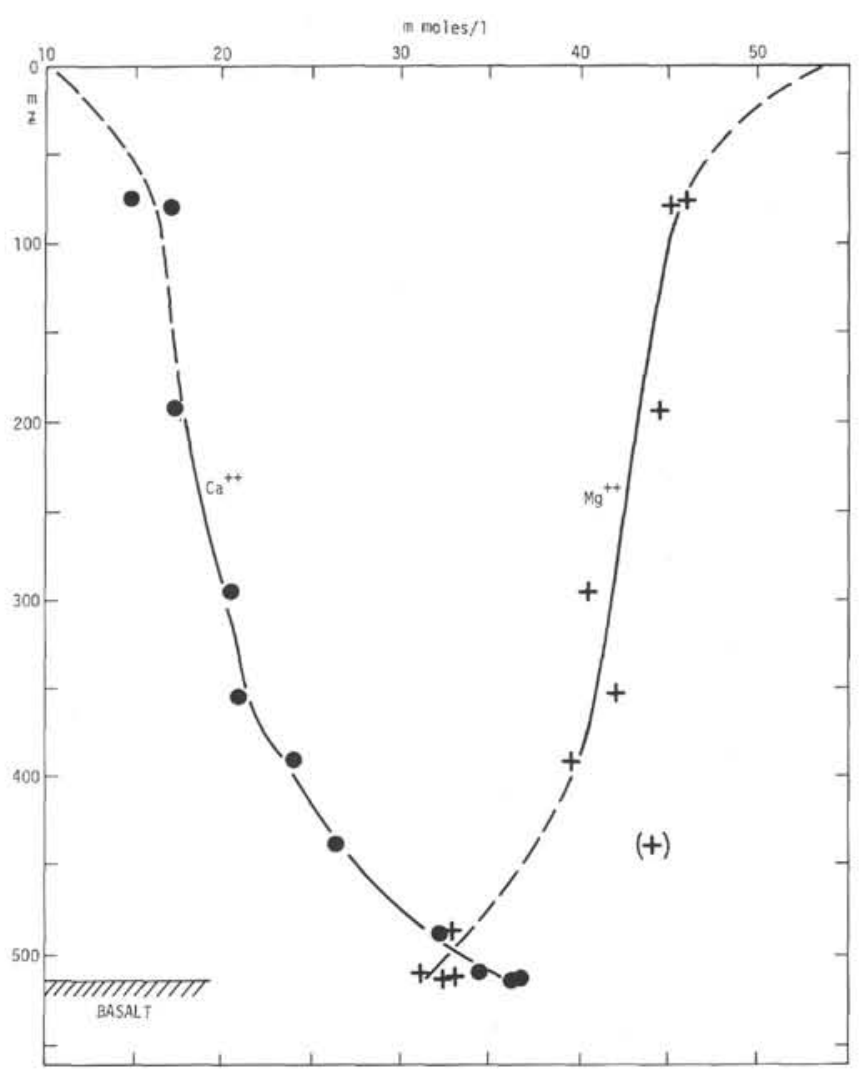

Figure 8. Calcium and magnesium, Site 322.

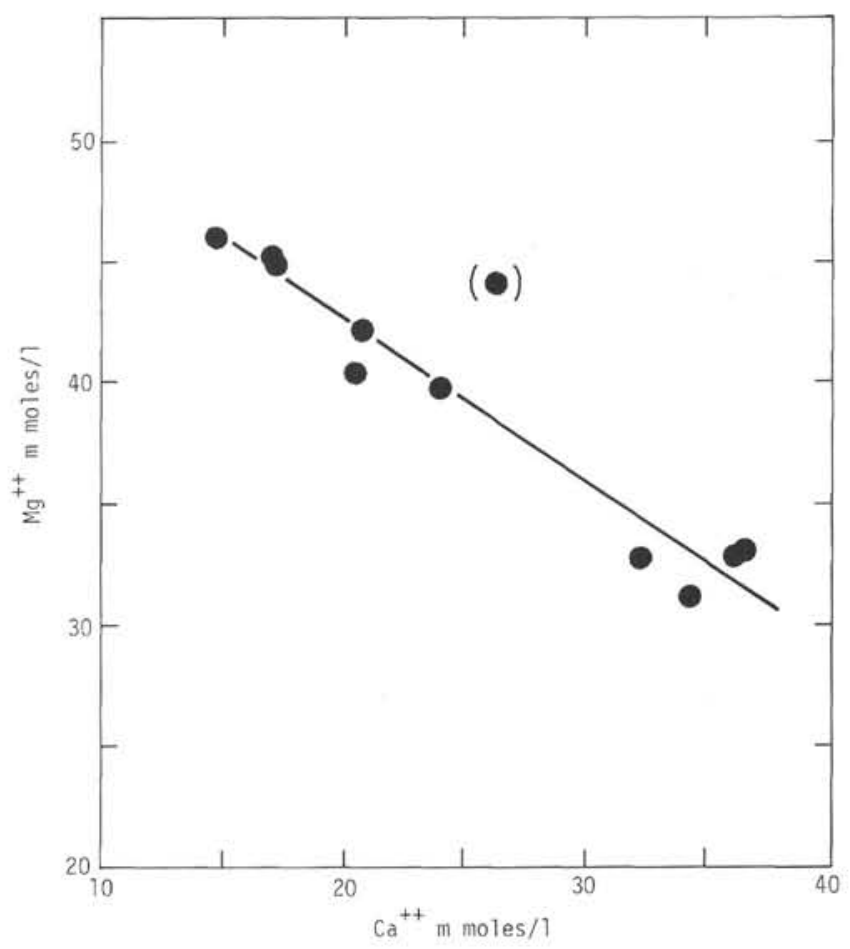

Figure 9. $\mathrm{Ca}^{++}$versus $\mathrm{Mg}^{++}$, Site 322.

Data for $\mathrm{K}^{+}$(Figure 11) suggest a sink either in the basal sediments or in the underlying basalts. Only a very small flux appears to be involved. 


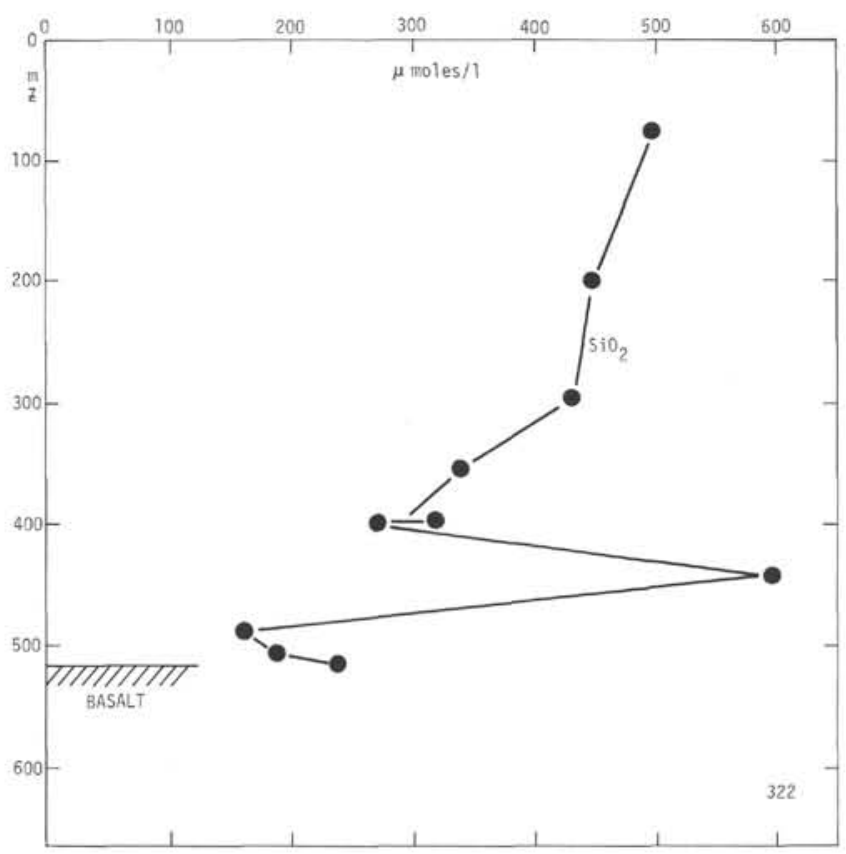

Figure 10. Silica, Site 322.

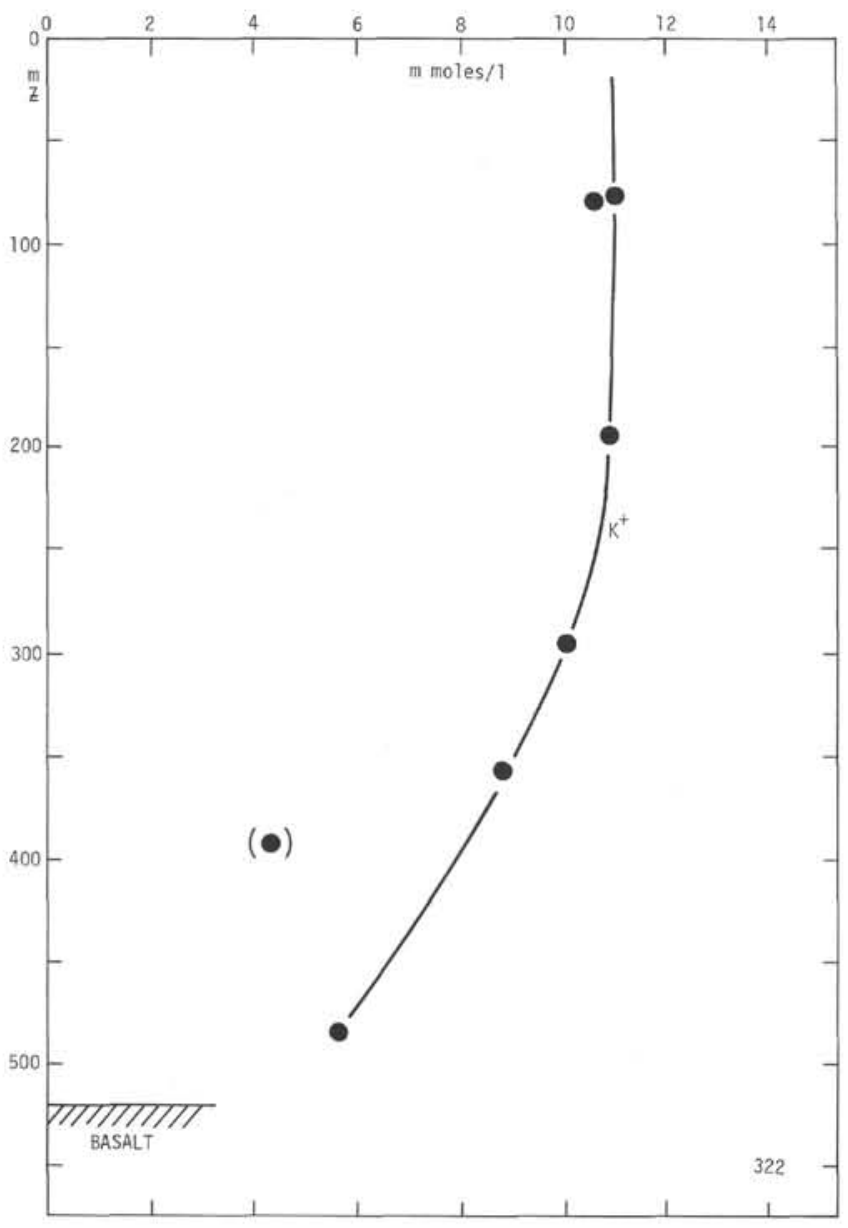

Figure 11. Potassium, Site 322.

Changes in the $\delta \mathrm{O}^{18}$ of the interstitial waters (Table 3, Figure 32) suggest that alteration reactions occurring in the basal sediments and basalts are not extensive (Lawrence et al., this volume).

\section{Site 323}

In this hole, significant reduction in dissolved sulfate occurs (Figure 14). Below 400 meters, values are essentially constant at about 12 mmoles/1. It is of interest that only a very small depletion in dissolved sulfate occurs in the rapidly deposited upper 170 meters. The main depletion in dissolved sulfate occurs between 200 and 400 meters. This depletion appears to be due to the bacterial reduction of sulfate, resulting in a maximum in $\mathrm{NH}_{4}{ }^{+}$at about 300 meters (Figure 15) and a maximum in alkalinity (Figure 13). The latter two constituents, i.e., $\mathrm{NH}_{4}{ }^{+}$and $\mathrm{HCO}_{3}{ }^{-}$, again show relatively small changes in the upper 170 meters, followed by much more rapid changes. It appears, therefore, that differences in amounts of reactive organic matter, as well as differences in sedimentation rates, have a pronounced influence on interstitial water gradients. This, of course, has been noticed before in Deep Sea Drilling Project holes (Gieskes, 1974, 1975). The deeper sediments at both Sites 322 and 323 appear to act as efficient sinks for dissolved $\mathrm{NH}_{4}{ }^{+}$, probably by ion exchange. Increases in alkalinity $\left(\mathrm{HCO}_{3}{ }^{-}\right)$do not match decreases in dissolved sulfate. This can best be understood in terms of calcium carbonate precipitation (Lawrence, 1973; Gieskes, 1975). The maximum in alkalinity at about 300 meters (Figure 13) represents the level at which the rate of production of $\mathrm{HCO}_{3}{ }^{-}$is equal to the rate of removal (Lawrence, 1973).

Data on dissolved manganese (Table 2) are variable but relatively high and suggest reducing conditions throughout the hole.

Dissolved calcium and magnesium (Figure 16) in the upper 170 meters suggest, again, reactions similar to those in the upper layers of Site 322. The profiles between 200 and 450 meters, especially when compared with Figure 3, suggest that at depths of $450 \pm 20$ meters reactions occur that involve uptake of $\mathrm{Mg}^{++}$and release of $\mathrm{Ca}^{++}$. The $\mathrm{Ca}^{++}$and $\mathrm{Mg}^{++}$data are linearly correlated, with $\triangle \mathrm{Ca}^{++} / \triangle \mathrm{Mg}^{++}=0.68$ (Figure 17). In the same interval, $\mathrm{SO}_{4}^{++}$is also linearly correlated with $\mathrm{Ca}^{++}$. Depletions in $\mathrm{Mg}^{++}$and $\mathrm{K}^{+}$amount to $74 \mathrm{meq} / \mathrm{l}$, whereas increases in $\mathrm{Ca}^{++}$are $44 \mathrm{meq} / 1$. The discrepancy of $30 \mathrm{meq} / 1$ is exactly equal to the depletion in dissolved sulfate. We interpret these observations in terms of a larger release of $\mathrm{Ca}^{++}$(equivalent to the uptake of $\mathrm{Mg}^{++}$and $\mathrm{K}^{+}$) than is noticeable in the interstitial water concentrations because of precipitation of authigenic calcite. This, then, explains the observations on the very slight changes in alkalinity discussed above.

Of interest here are the observations of Kastner (this volume), who finds that the formation of cherts in Core $9(465 \mathrm{~m})$ is associated with in situ alteration reactions involving calcium plagioclase (source for $\mathrm{Ca}^{++}$), with the formation of smectite (sink for $\mathrm{Mg}^{++}$) and authigenic $\mathrm{K}$-feldspar (sink for $\mathrm{K}^{+}$). We feel that this has established clearly for the first time that interstitial water gracients of $\mathrm{Ca}^{++}, \mathrm{Mg}^{++}$, and $\mathrm{K}^{+}$can be interpreted in terms of a reaction site and actually identifiable reactions.

Below 450 meters, $\mathrm{Mg}^{++}$decreases toward basaltic basement, whereas $\mathrm{Ca}^{++}$shows a sharp increase $\left(\triangle \mathrm{Ca}^{++} / \triangle \mathrm{Mg}^{++} \cong 2\right.$, Figure 17). Dissolved sulfate shows little change, whereas alkalinity (and total $\mathrm{CO}_{2}$ content) decreases toward the bottom of the hole. We 


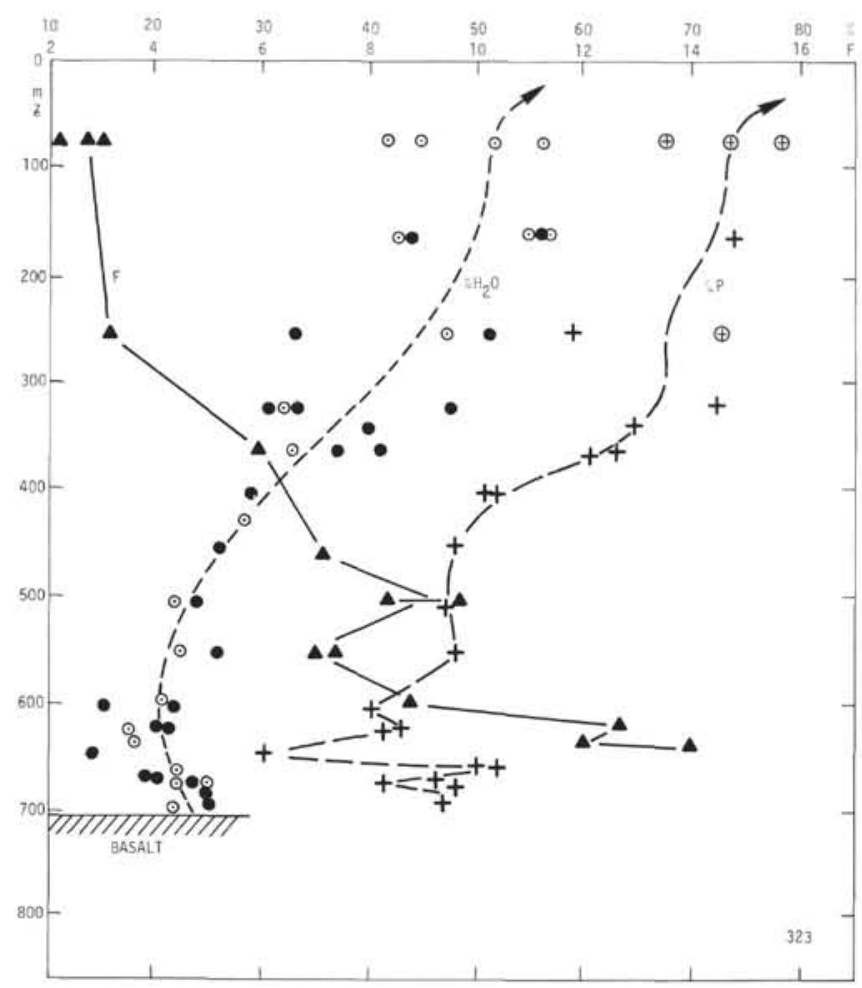

Figure 12. Formation factors (F), water contents, and porosities, Site 323.

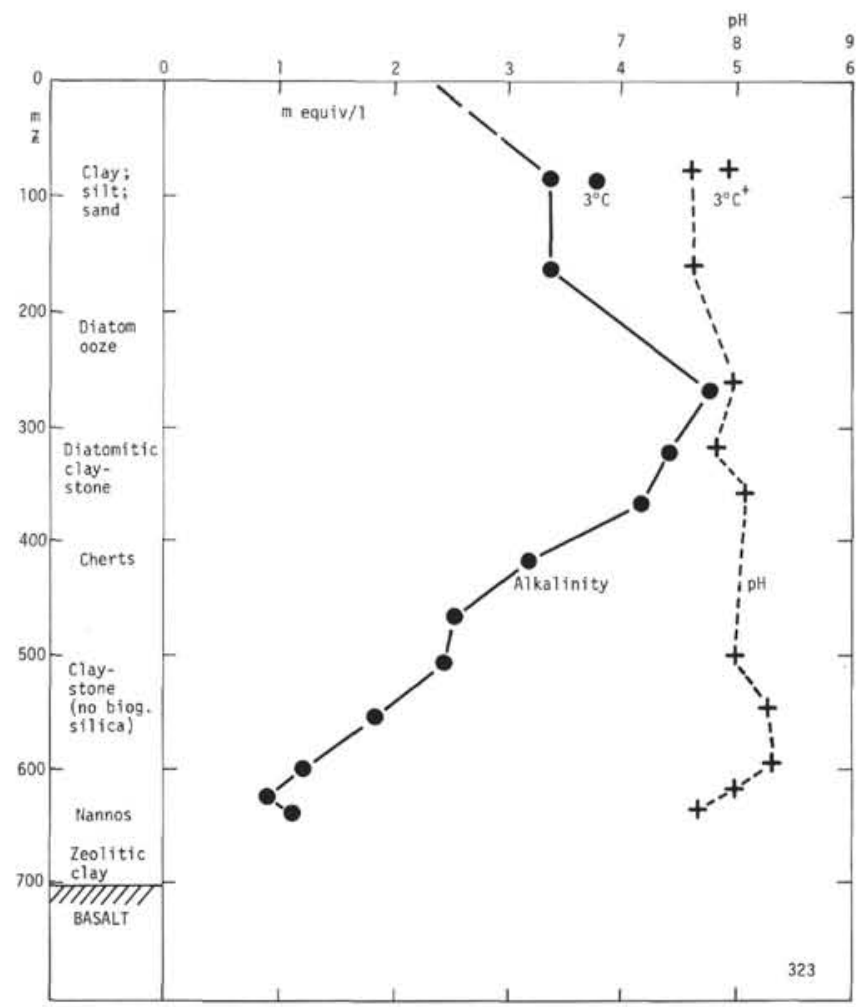

Figure 13. Lithology, $p H\left(25^{\circ} \mathrm{C}\right)$, and alkalinity, Site 323.

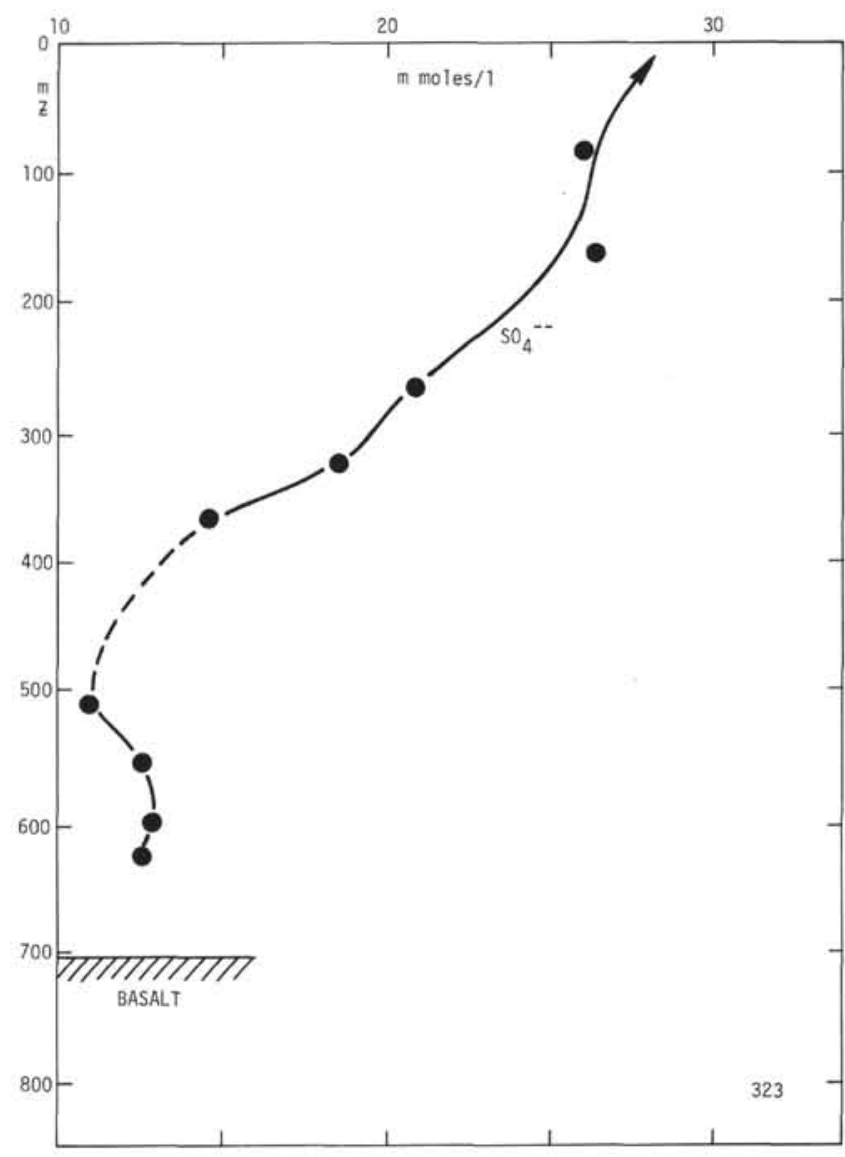

Figure 14. Sulfate, Site 323.

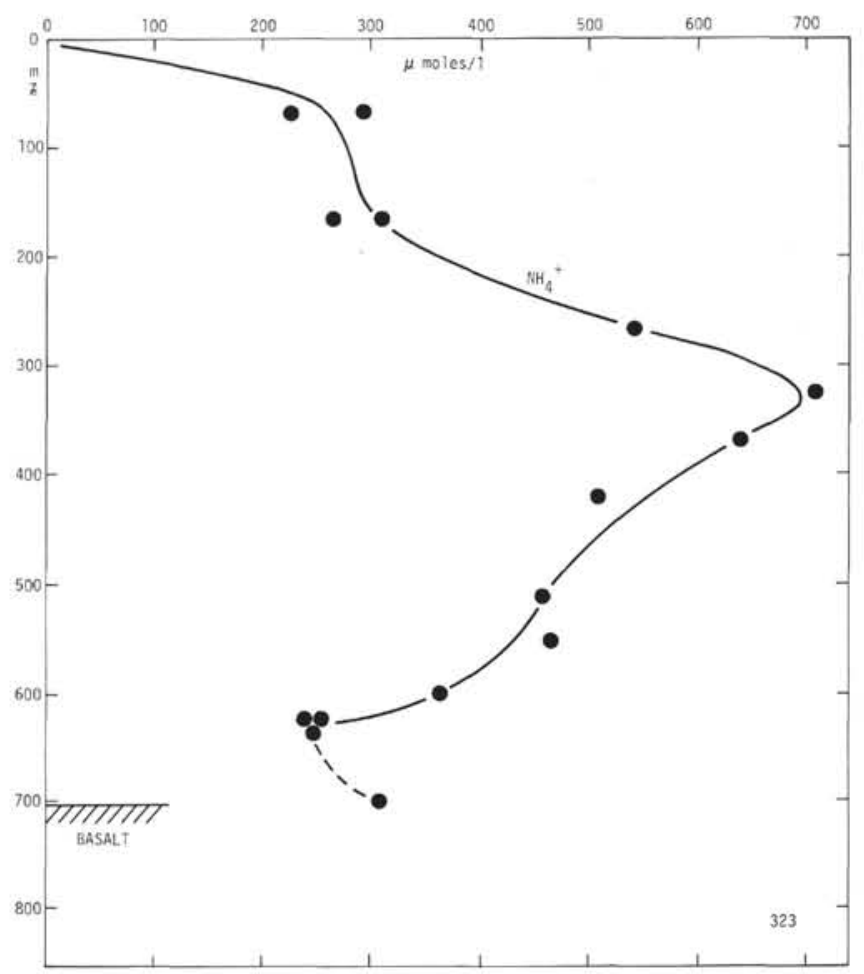

Figure 15. Ammonia, Site 323. 


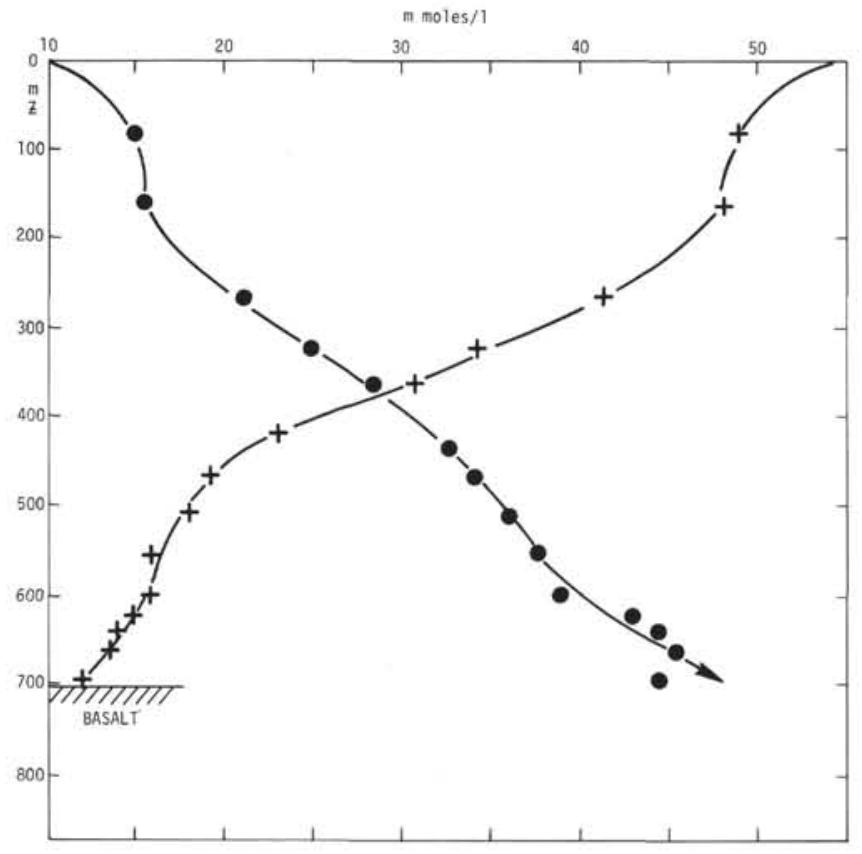

Figure 16. Calcium and magnesium, Site 323.

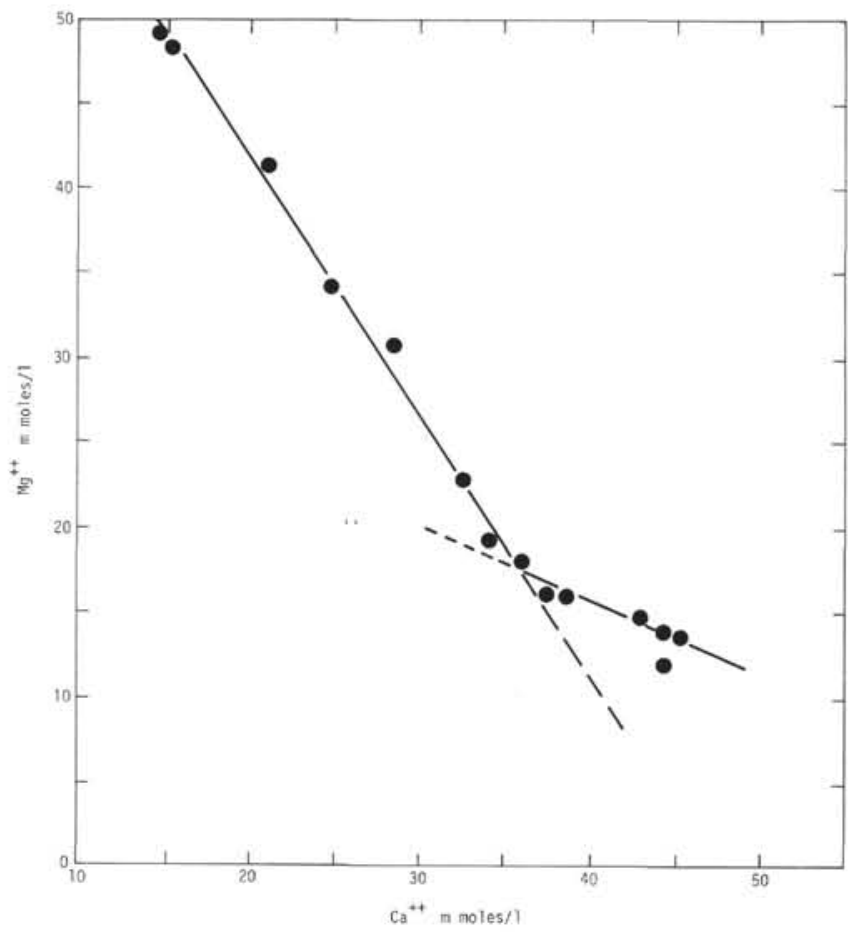

Figure 17. $\mathrm{Ca}^{++}$versus $\mathrm{Mg}^{++}$, Site 323.

interpret this in terms of continued alteration of volcanic matter in the basal sediments or in the underlying basalts. Decreases in $\mathrm{K}^{+}$and perhaps $\mathrm{Na}^{+}$balance the excess $\mathrm{Ca}^{++}$(over $\mathrm{Mg}^{++}$) gain. The latter component $\mathrm{Na}^{+}$would change by only about $3 \%-4 \%$, an amount too small to be significantly detectable. Drever (this volume) reports $\mathrm{Mg} / \mathrm{Al}$ ratios of the clay mineral fraction in these sediments, and these data suggest a slight increase in the $\mathrm{Mg} / \mathrm{Al}$ ratio in the lowermost section. Of course,

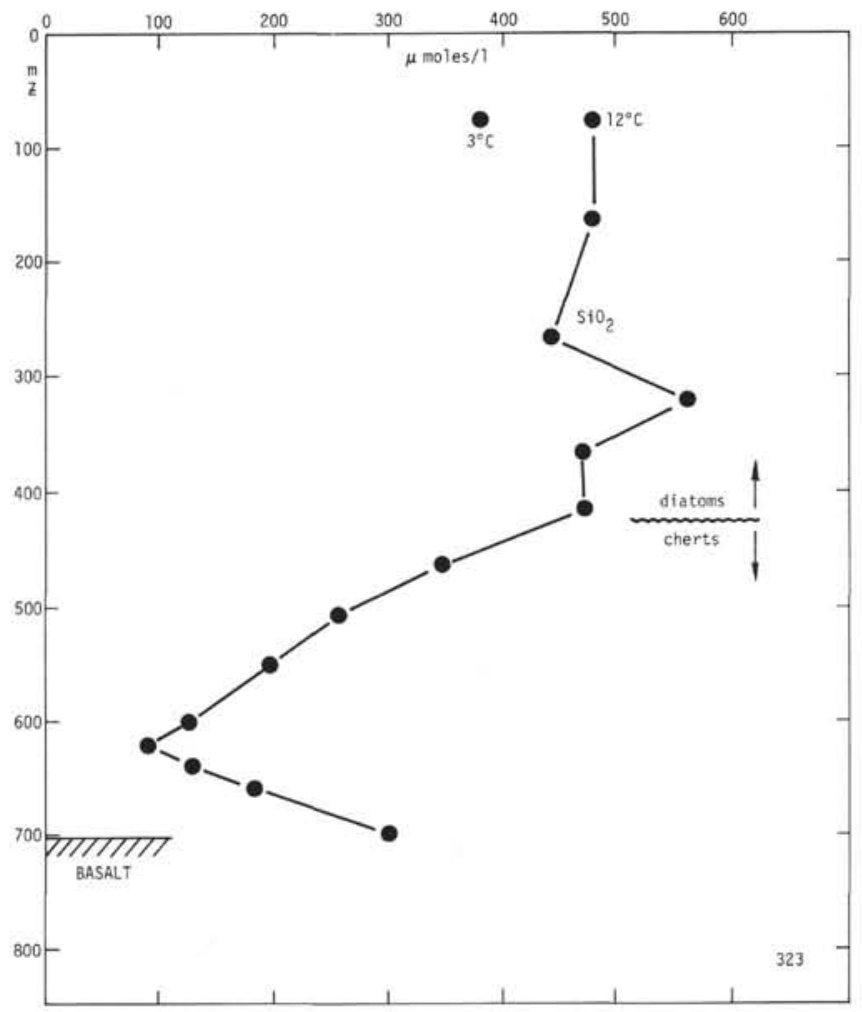

Figure 18. Silica, Site 323.

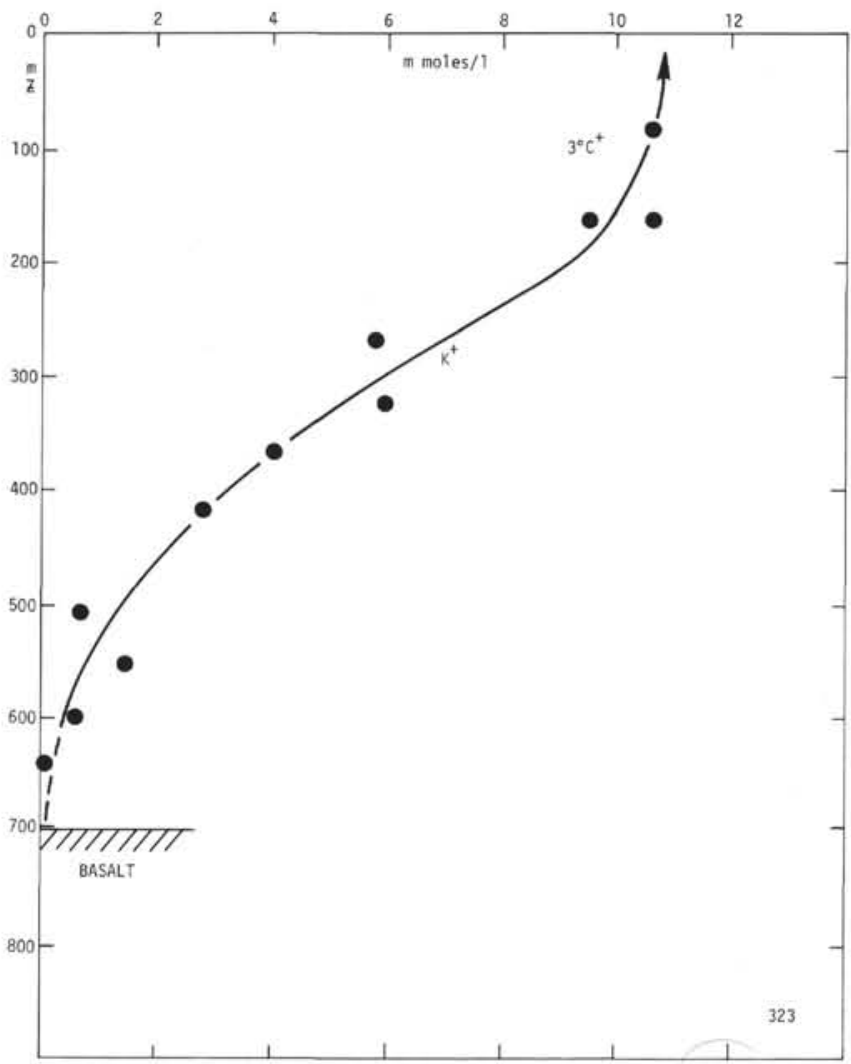

Figure 19. Potassium, Site 323. 
low temperature alteration of the underlying basalts may also act as an important sink for $\mathrm{Mg}^{++}$and source for $\mathrm{Ca}^{++}$.

Dissolved silica (Figure 18) values are relatively constant at $480 \mu$ moles $/ 1$ in the upper 400 meters, possibly reflecting the presence of opaline silica. Below the chert layers, however, a linear decrease occurs to 610 meters, after which, in the brown clays, a slight increase occurs. The latter increase may be related to possible authigenic reactions, whereas the profile between 400 and 610 meters suggests a pure diffusional gradient between two end members (cf., Figure 3).

The dissolved potassium (Figure 19) profile suggests uptake of $\mathrm{K}^{+}$at about 450 meters (K-feldspar?) as well as in the basal dark clay sediments (zeolites?). Also, a possible sink may be celadonite, detected in veins in altered basalt (Kastner, this volume). Again, little, if any, uptake occurs in the upper 170 meters.

Data on $\delta \mathrm{O}^{18}$ of the interstitial waters (Table 3, Figure 32) indicate a significant amount of alteration in the deeper sediments or in the underlying basalts. It is not clear how much of the depletion of $\delta \mathrm{O}^{18}$ is caused by the reactions occurring around 450 meters.

\section{Site 324}

This site is characterized by high sedimentation rates $(\sim 5.5 \mathrm{~cm} / 1000 \mathrm{yr})$, and only a depth of 220 meters was reached. The hole is characterized by sulfate reduction processes, the decrease in $\mathrm{SO}_{4}^{--}$being linear with depth (Figure 22). Data on the formation factor (Figure 20) imply approximate constancy in the factor $D_{O} / F$ of Equation 7 between 50 and 150 meters. For $D^{\prime}$ constant, a linear gradient would suggest steady-state diffusion without significant reaction. It appears, therefore, that reactions responsible for depletion in sulfate are located in the deeper part of the cored section. For this purpose, it is of interest to inspect the profiles of alkalinity (Figure 21) and ammonia (Figure 24). Both of these profiles show a maximum at about 140 meters, suggesting a major site for sulfate reduction at this level. This is also the level where dissolved silica shows a rapid change in concentration (Figure 24).

Dissolved calcium shows a broad maximum at about 140 meters (Figure 23), whereas dissolved magnesium decreases linearly with depth. At 150 meters, one observes the following changes in concentration: $\Delta \mathrm{Ca}^{++}=+9 \mathrm{mmoles} / 1, \Delta \mathrm{Mg}^{++}=-18 \mathrm{mmoles} / 1$, $\Delta \mathrm{SO}_{4}=-20 \mathrm{mmoles} / 1, \Delta \mathrm{K}^{+}=9 \mathrm{mmoles} / 1$, and $\mathrm{Cl}^{-}$has remained essentially constant (Table 1). This leaves a quantity of $13 \mathrm{meq}$ of cations to be balanced by a decrease in $\mathrm{Na}^{+}$or an increase in alkalinity. The latter increase is only $2 \mathrm{meq} / 1$, leaving a decrease in 11 mmoles/1 of $\mathrm{Na}^{+}(?)$, or about $2 \%$ of the sodium, to be accounted for. This balance, of course, does not explain any of the observed changes, but it is a confirmation of the accuracy of the data obtained. Throughout the cored section, increases in dissolved calcium occur. As at Site 323 , actual increases in $\mathrm{Ca}^{++}$must have been considerably larger, and calcium carbonate precipitation accounts for the relatively small increases in alkalinity. Typically "recrystallized" calcite is reported by shipboard sedimentologists, material that is probably a primary precipitate which is light in $\delta \mathrm{C}^{13}$ (cf., Anderson

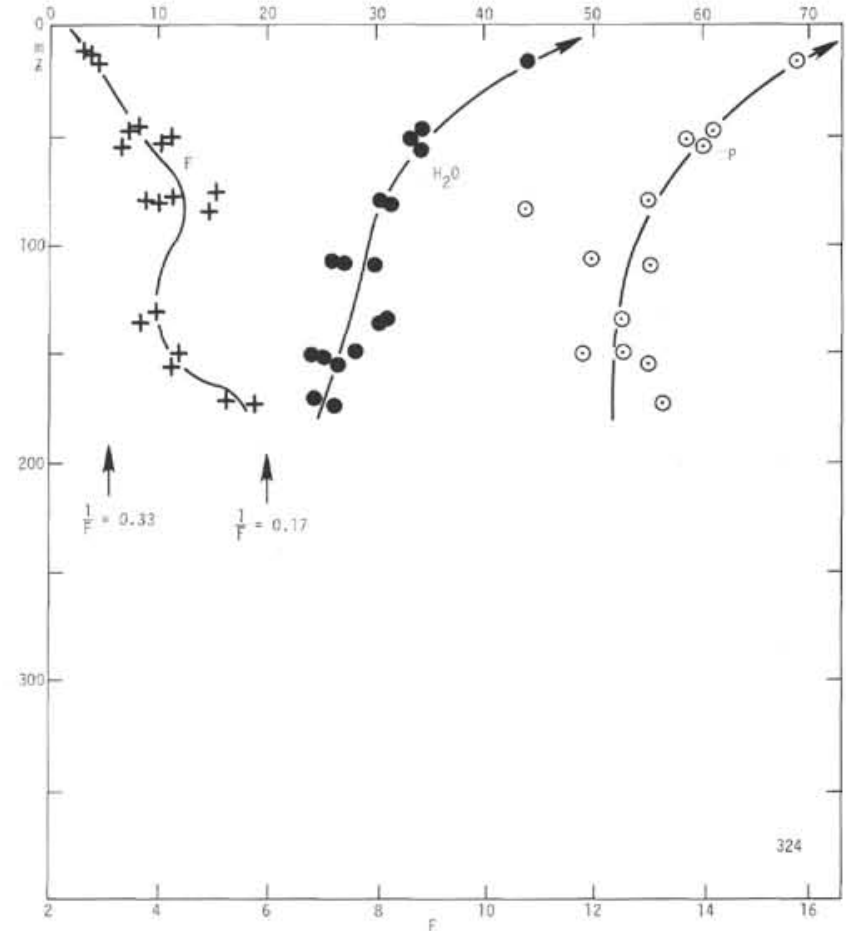

Figure 20. Formation factors (F), water contents, and porosities, Site 324.

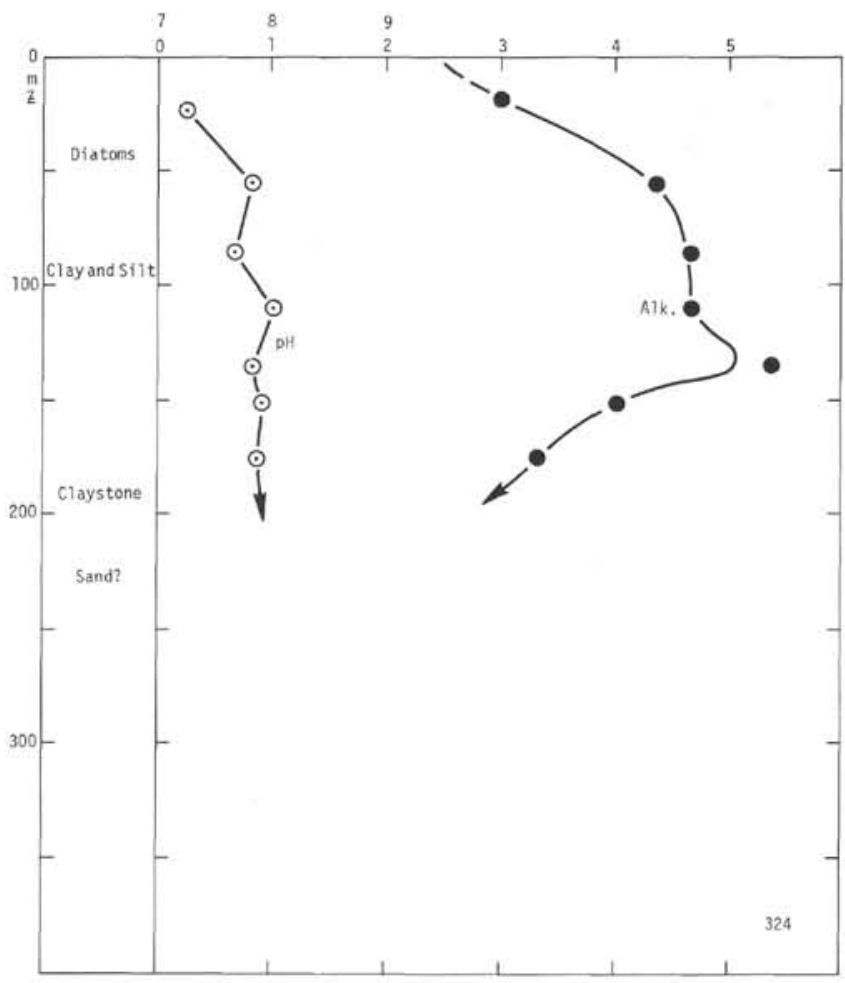

Figure 21. Lithology, $\mathrm{pH}\left(25^{\circ} \mathrm{C}\right)$, and alkalinity, Site 324 .

and Lawrence, this volume). Of interest is the maximum in dissolved calcium at about 125 meters. Dissolved silica (Figure 24) changes abruptly below 108 meters, indicating a change in lithology. Zemmels and Cook (this volume) report the presence of small amounts of clinop- 


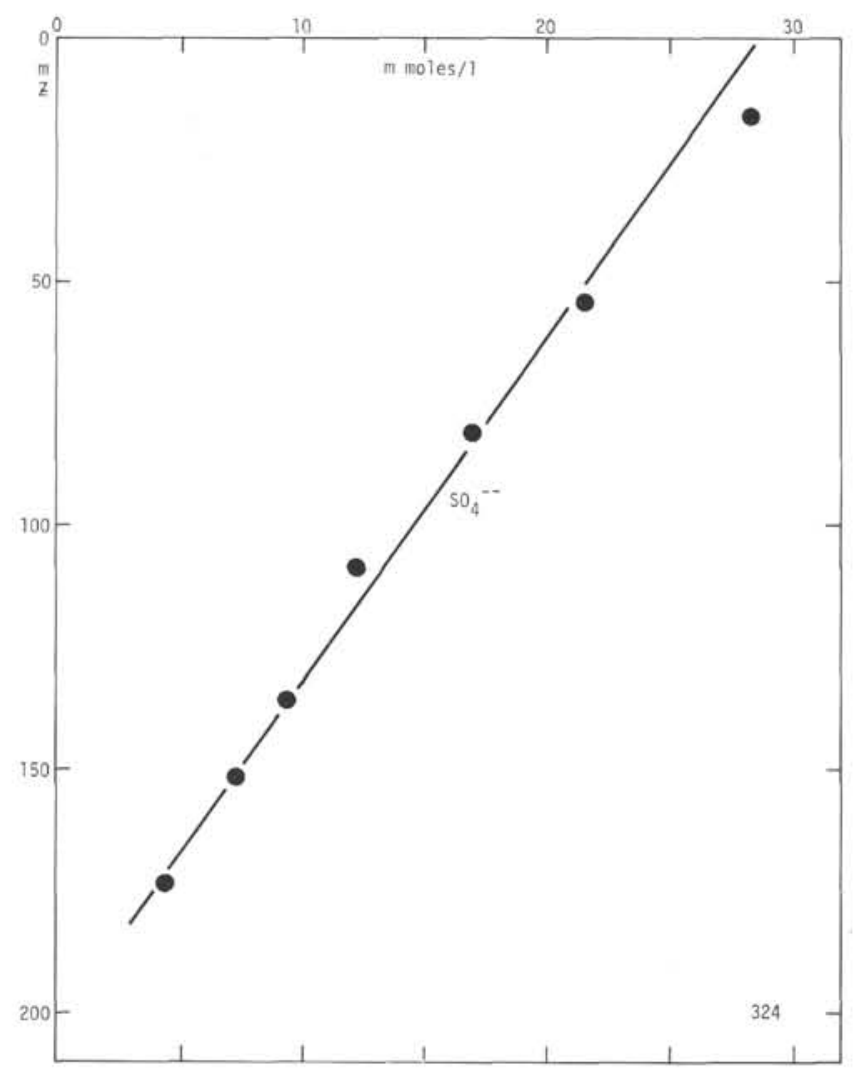

Figure 22. Sulfate, Site 324.

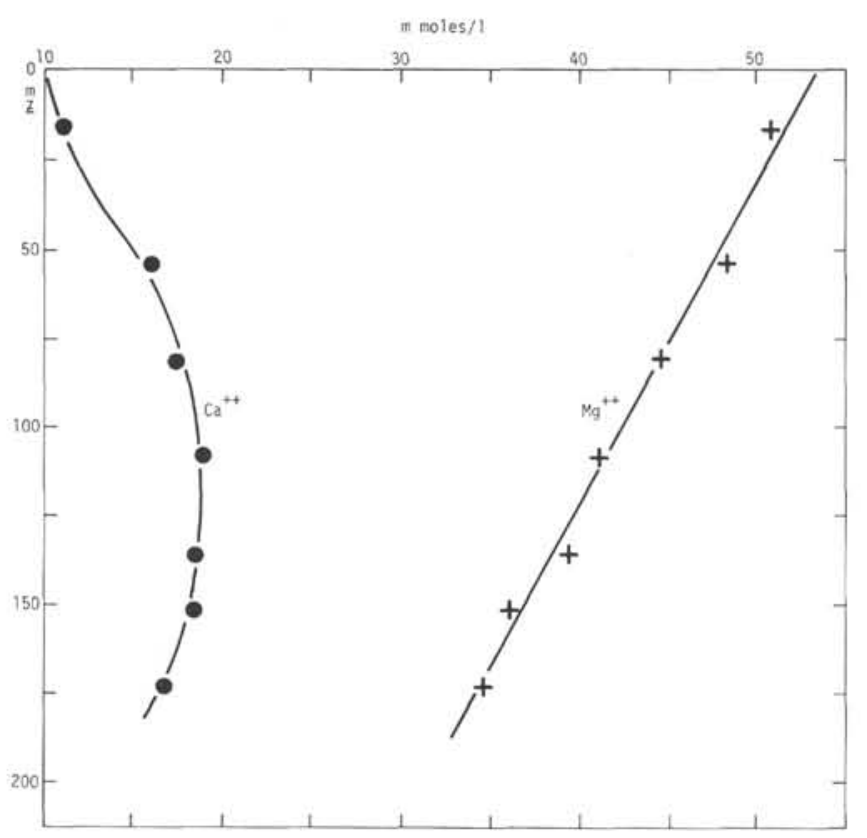

Figure 23. Calcium and magnesium, Site 324.

tilolite above 125 meters. If this material is a product of in situ weathering reactions of volcanic glass or terrigenous material, then the dissolved calcium increase could result from these alteration reactions. Substantial sulfate reduction reactions in the deeper parts of the core could then produce large amounts of $\mathrm{HCO}_{3}{ }^{-}$and lead to the precipitation of calcite, yielding the observed

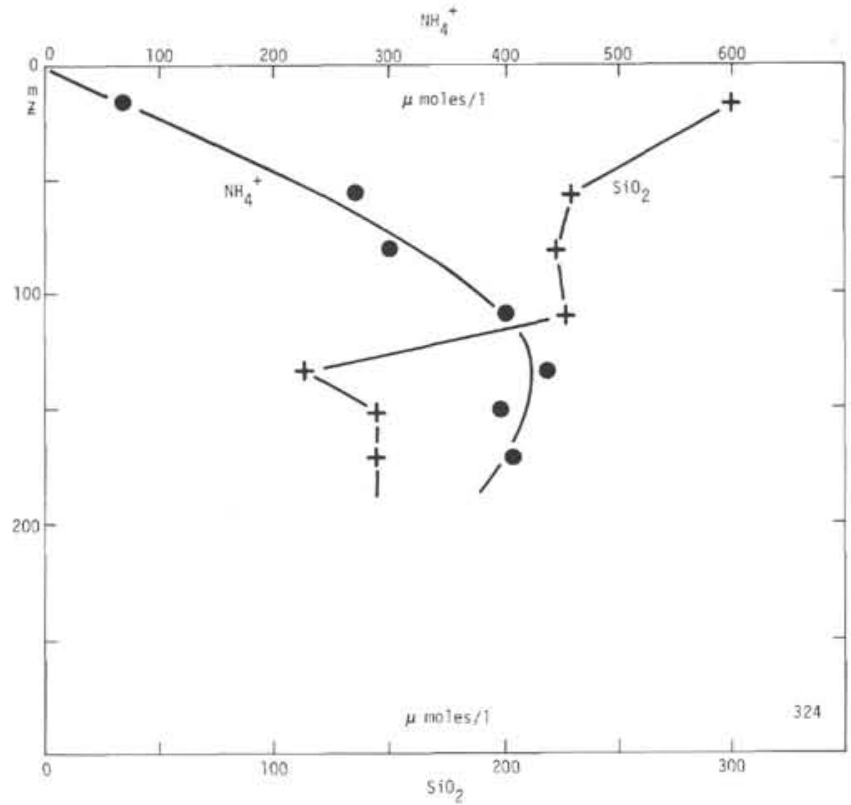

Figure 24. Ammonia and silica, Site 324.

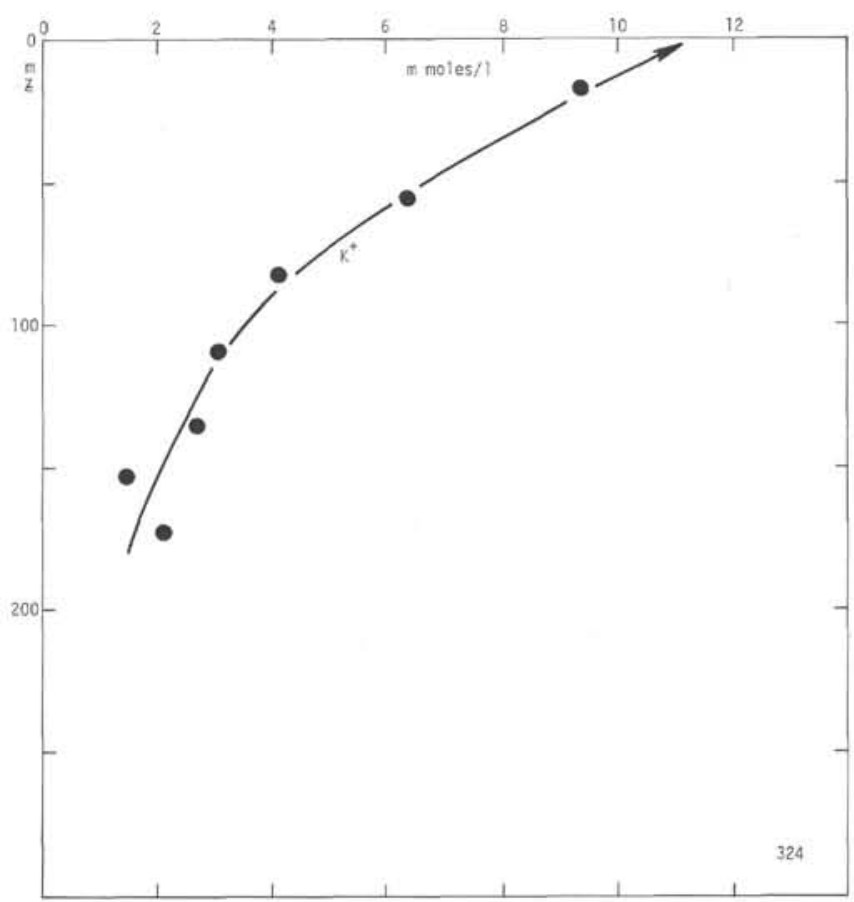

Figure 25. Potassium, Site 324.

maxima in $\mathrm{Ca}^{++}$and $\mathrm{HCO}_{3}{ }^{-}$. The above weathering reactions could also be responsible, at least in part, for the depletions in $\mathrm{Mg}^{++}$and $\mathrm{K}^{+}$(Figure 25) in the interstitial waters. The data do not allow the precise localization of the reaction sites, but perhaps reactions are more extensive toward the deeper part of the hole, particularly with regard to possible sulfate reduction processes.

It is tempting to suggest that the mechanism proposed by Drever (1971) can account for the depletion of $\mathrm{Mg}^{++}$, i.e., iron released by chlorite during sulfate reduction is replaced by $\mathrm{Mg}^{++}$in a nonexchangeable position in the 
clay lattice and the iron is subsequently precipitated as an iron sulfide (pyrite). Such a mechanism would account for the co-variance of $\mathrm{SO}_{4}{ }^{--}$and $\mathrm{Mg}^{++}$. It would not, however, account for the release of $\mathrm{Ca}^{++}$and the relatively large depletion in $\delta \mathrm{O}^{18}$ (Figure 32 ).

\section{Site 325}

The upper 400 meters of this hole are characterized by very rapid sedimentation rates, particularly in the Oligocene (Figure 1). Dissolved sulfate values (Table 1) decrease rapidly to about $13 \pm 1$ mmoles/ 1 at about 180 meters. Simultaneously, alkalinity values (Figure 27) rise to a maximum of $5 \mathrm{meq} / 1$ at 180 meters. Involvement of bacterial sulfate reduction appears to be again confirmed by sharp increases in dissolved ammonia (Figure 28). The maximum value in $\mathrm{NH}_{4}{ }^{+}$occurs at about 400 meters, below which it drops rapidly to a constant value. As the sediments below 400 meters have been deposited at much slower rates, sulfate reduction may never have been important in these lower sections, so that a sink for ammonia ions is readily available.

Magnesium concentrations decrease rapidly to 400 meters, with a small concurrent increase in calcium (Figure 29). Alteration reactions of continental debris (Peters and Hollister, this volume), as well as processes suggested under Site 324, may be involved. In view of the rapid sedimentation rates, most of these changes must have originated within the sediment section.

Below 400 meters, decreases in $\mathrm{Mg}^{++}$continue, and the concentration becomes essentially zero below 500

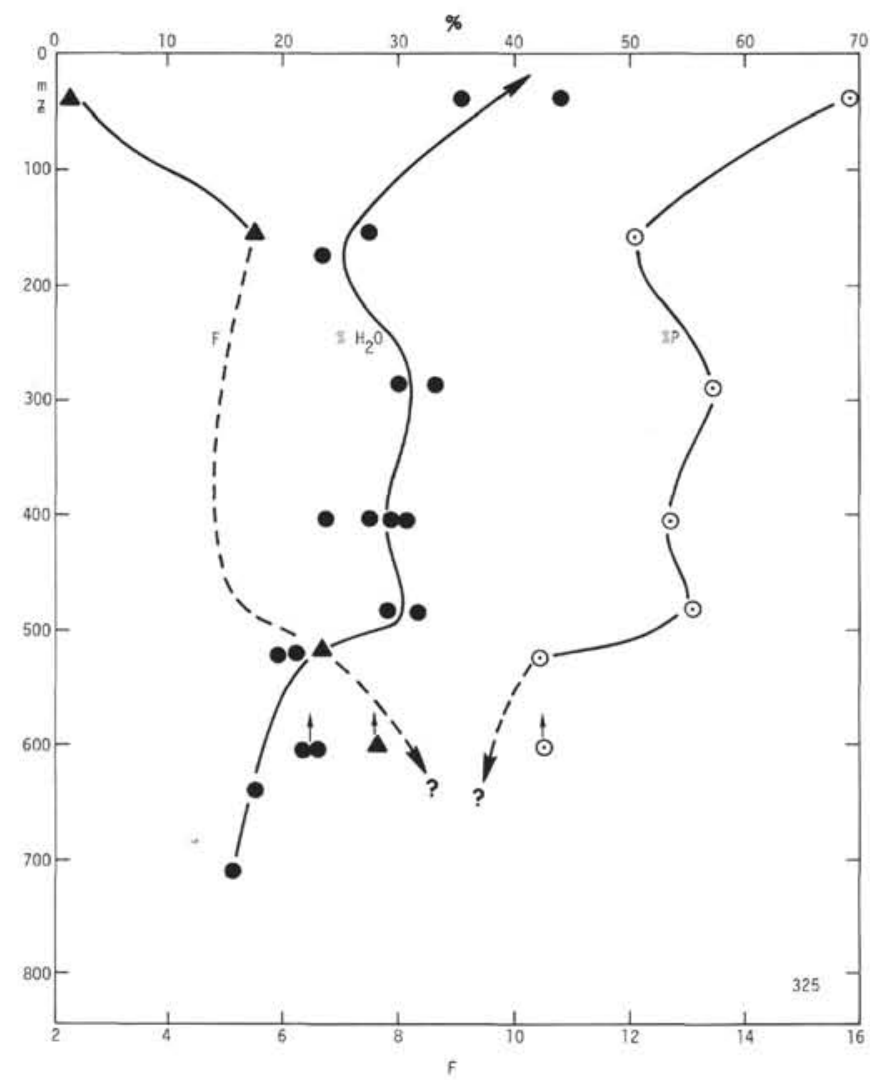

Figure 26. Formation factors (F), water contents, and porosities, Site 325 .

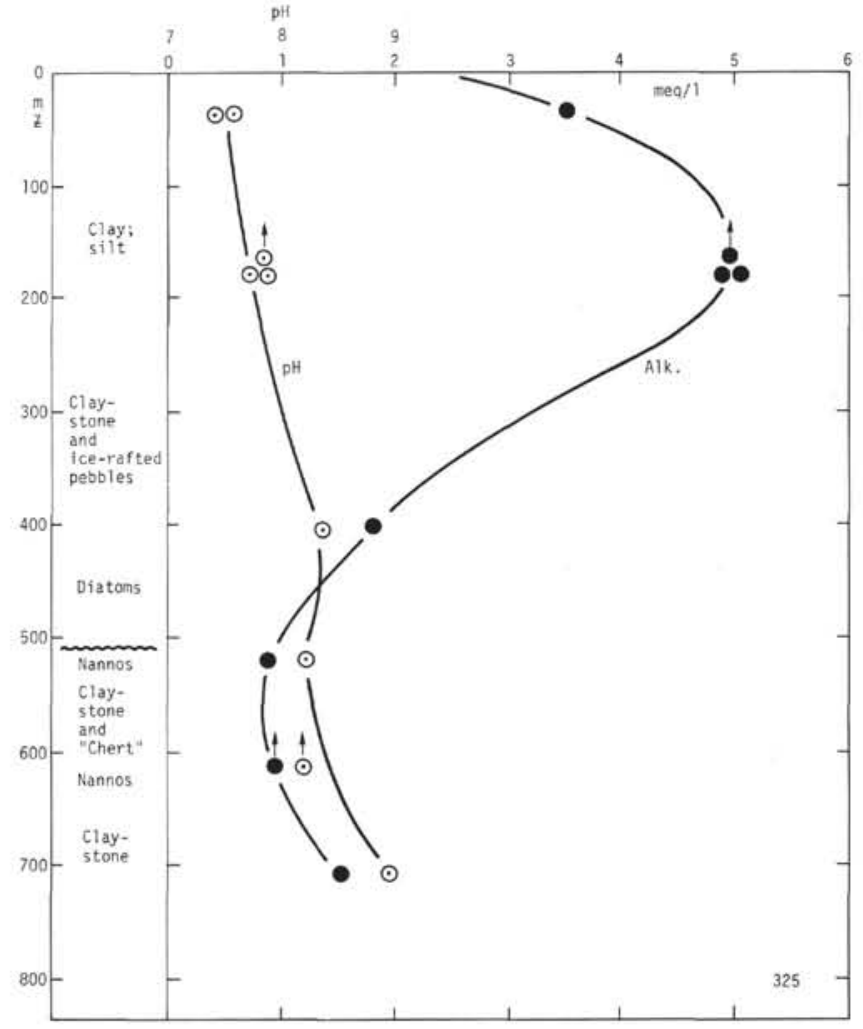

Figure 27. Lithology, $p H\left(25^{\circ} \mathrm{C}\right)$, and alkalinity, Site 325 .

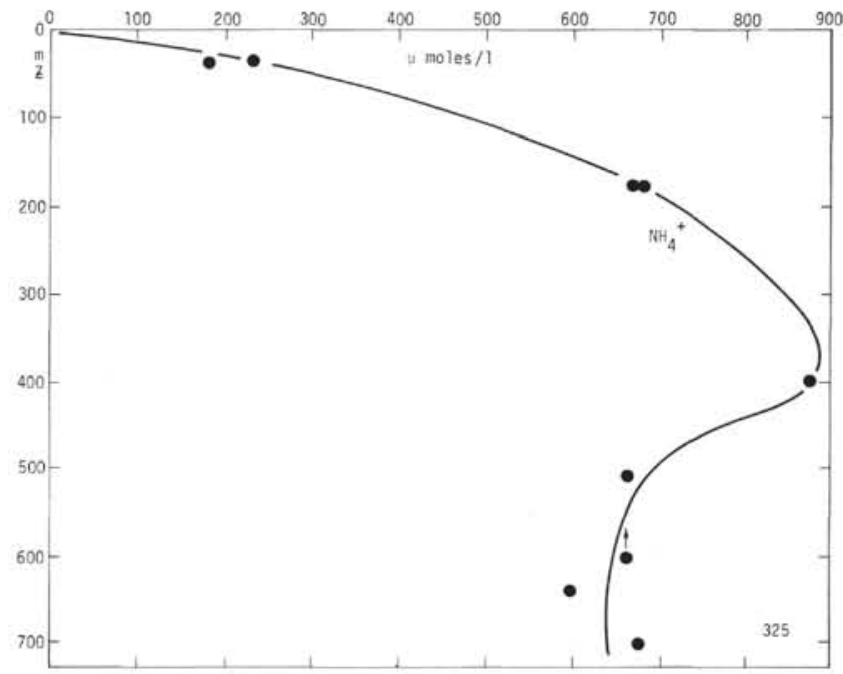

Figure 28. Ammonia, Site 325.

meters. This is in the zone where cherts and cristoballite are found (see site reports; Zemmels and Cook, this volume). Increases in the $\mathrm{Ca}^{++}$concentration, however, continue to the deepest point sampled.

Of interest here are the data for Core 8. Shipboard geochemists had suspected that "washing" of sediments over 100-meter intervals might result in retrieval of sediment "clumps" not necessarily representative of assigned sampling depth. After recovery of Core 7, the sediment was washed to 600 meters, we analyzed various samples from the top of Core 8 to the core catcher 


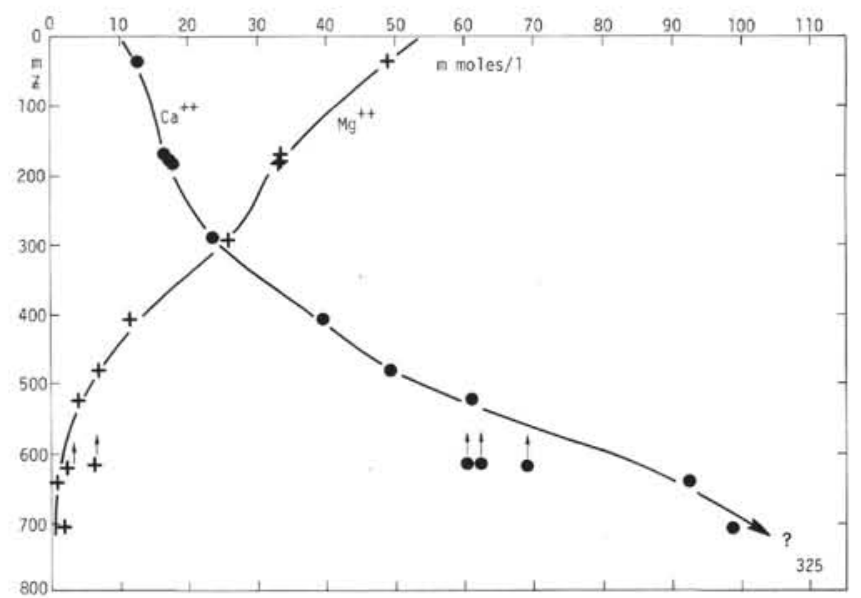

Figure 29. Calcium and magnesium, Site 325.

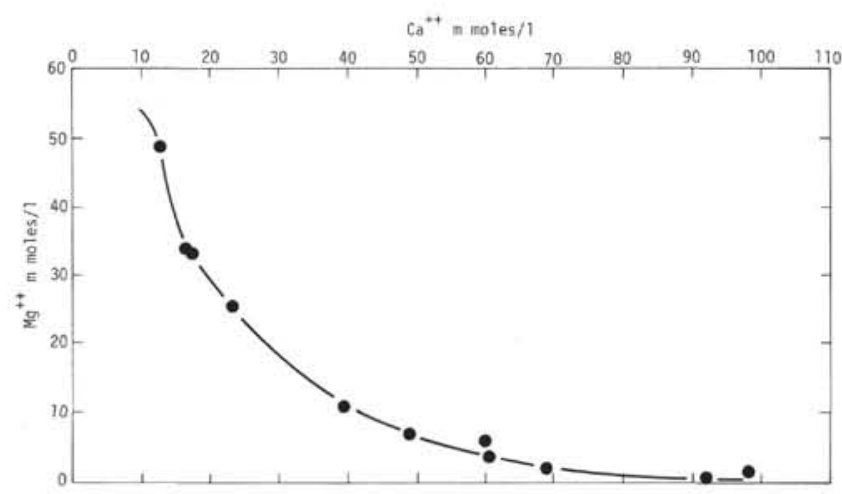

Figure 30. $\mathrm{Ca}^{++}$versus $\mathrm{Mg}^{++}$, Site 325 .

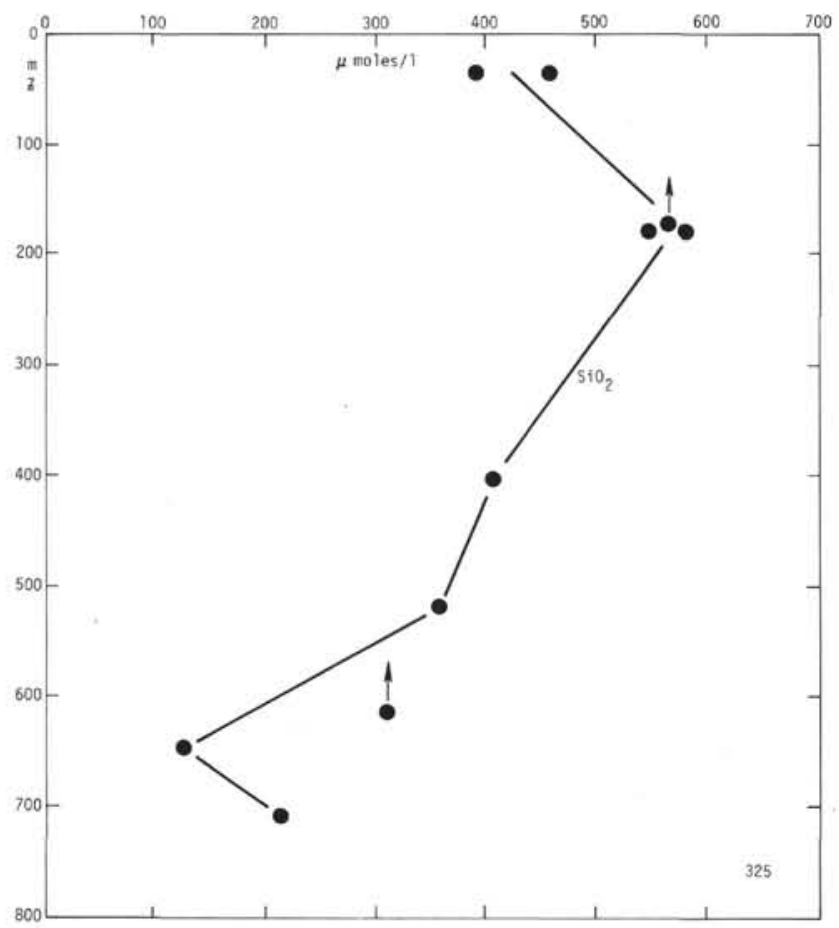

Figure 31. Silica, Site 325.
(Table 1; Figure 29), and the dissolved calcium data suggest that even the core-catcher sample is probably representative of sediment at $530 \pm 10$ meters, rather than sediment at 600 meters. These data show the inherently dangerous effects of washing on stratigraphic control, as well as the advantage of interstitial water analyses to correct samples to true depth (provided, of course, that gradients exist).

The large increases in dissolved calcium in the deeper part of the hole may be related to alteration reactions in the sediments underlying the last core or in the basalt basement (unsampled) itself. Changes in $\delta \mathrm{O}^{18}$ in the deeper part of the hole strongly suggest alteration reactions of volcanic or basaltic matter.

Dissolved silica data are erratic (Figure 31) and do not warrant much discussion at this stage.

\section{TABLE 3}

$\delta 0^{18}$ Data,

Interstitial Water, Leg 35

\begin{tabular}{ccc}
\hline Site & $\begin{array}{c}\text { Depth } \\
(\mathrm{m})\end{array}$ & $\delta \mathrm{O}^{18}$ (SMOW) \\
\hline 322 & 80 & $+0.1 \pm 0.1$ \\
& 300 & $-0.1 \pm 0.1$ \\
323 & 490 & $-0.3 \pm 0.5$ \\
& 80 & $-0.6 \pm 0.1$ \\
& 260 & $-0.2 \pm 0.3$ \\
& 364 & $-1.4 \pm 0.4$ \\
& 506 & $-1.9 \pm 0.2$ \\
324 & 660 & $-3.5 \pm 0.2$ \\
& 50 & $+0.2 \pm 0.2$ \\
325 & 175 & $-0.7 \pm 0.1$ \\
& 40 & $+0.3 \pm 0.2$ \\
& 175 & $0.0 \pm 0.1$ \\
& 620 & $-2.4 \pm 0.3$ \\
& 710 & $-2.5 \pm 0.1$ \\
\hline
\end{tabular}

\section{GENERAL DISCUSSION}

\section{Diagenesis}

At all sites studied during Leg 35 , the gradients in concentration of the major and some minor constituents of the interstitial waters suggest the presence of significant reactions.

At most sites drilled during DSDP and characterized by rapid sedimentation rates and extensive sulfate reduction, increases in alkalinity are generally accompanied by initial decreases in dissolved calcium (Manheim and Sayles, 1974; Gieskes, 1975). Notorious exceptions to this are sites drilled in the Antarctic Ocean during Leg 28 (Mann and Gieskes, 1975) and Leg 35. These observations suggest a significant source of calcium in the sediments that is absent elsewhere. The most likely sources are continental igneous debris that has been redeposited from continental shelf areas and ice-rafted material (Peters and Hollister, this volume). Weathering of this material after burial could lead to a rise in dissolved $\mathrm{Ca}^{++}$and a simultaneous depletion in dissolved $\mathrm{Mg}^{++}$. Bicarbonate ions released during sulfate reduction could then still react with $\mathrm{Ca}^{++}$to precipitate calcite and yet maintain $\mathrm{Ca}^{++}$values higher than those of present-day seawater. In the absence of an 
exact knowledge of the reactions involved, we cannot consider any mass balances that would result from such reactions. It appears, however, that the above reactions are of importance at all sites in the upper, rapidly deposited Pliocene sediments.

In the deeper parts of the various sites, more reactions involving uptake of $\mathrm{Mg}^{++}$and $\mathrm{K}^{+}$and release of $\mathrm{Ca}^{++}$ do occur, as is best demonstrated at sites 323 and 325 . At the former site, weathering reactions of volcanic materials in the chert zone of Core 9 (Kastner, this volume) appear as the main reactions, whereas at Sites 322 and 325 increases in apparently authigenic 100\%expandable smectite (Perry and Beckles, this volume) can best be explained as the result of the lowtemperature alteration of volcanogenic material. Data on $\mathrm{O}^{18} / \mathrm{O}^{16}$ ratios in the interstitial waters, as well as on those in the silicate and clay mineral fractions (Eslinger and Savin, Anderson and Lawrence, this volume) support these conclusions.

Finally, uptake of $\mathrm{Mg}^{++}$and $\mathrm{K}^{+}$in the lowtemperature alteration of basalt and the simultaneous release of $\mathrm{Ca}^{++}$must be important in these holes, which would explain the continuation of the observed concentration gradients of $\mathrm{Ca}^{++}, \mathrm{K}^{+}, \mathrm{Mg}^{++}$, and $\mathrm{HCO}_{3}{ }^{-}$to the basalt-sediment interface.

\section{Mass Balance Considerations}

A major point for consideration in interstitial water studies is the question of what amounts of material are involved in processes that lead to the uptake or release of materials into the interstitial fluids.

Donnelly and Wallace (this volume) point out that only very minor changes in the $\mathrm{K} / \mathrm{Al}, \mathrm{Mg} / \mathrm{Al}$, and $\mathrm{Ca} / \mathrm{Al}$ ratios occur in the bulk sediment chemistry. Chemical analyses of the clay fractions at Site 323 show, in fact, a large decrease in the $\mathrm{K} / \mathrm{Al}$ ratio in the basal sediments and no abnormally large increase in the $\mathrm{Mg} / \mathrm{Al}$ ratio. The problem arises, therefore, of the magnitude of the diffusional flux contributing ions to the sediments, or vice versa.

The problem can best be demonstrated with Site 323 as an example. The interstitial water data below 200 meters suggest a major sink for magnesium ions in the chert zones below 400 meters. In the case where the $\mathrm{Mg}^{++}$gradient of about 12.5 mmoles/1-100 meters has persisted since deposition, one estimates a time of about $15 \times 10^{6} \mathrm{yr}$, or less, over which diffusion may have occurred. Thus, over this period, one can calculate, using the data of Figure 3, a flux of about $19 \mathrm{~g}$ of $\mathrm{Mg}$ per $\mathrm{cm}^{2}$ of sediment. If the sink were uniformly distributed over a sediment column of 50 meters (porosity $70 \%$ ), an amount of $0.49 \% \mathrm{Mg}$ would be added to the sediment. At a porosity of $50 \%$, this amount would still be $0.34 \% \mathrm{Mg}$. Such an addition is not apparent from the data of Donnelly and Wallace (this volume). Perhaps the estimated time for diffusion may have been grossly overestimated or the assumption of a constant gradient with time may be erroneous. It is quite possible that reaction rates are very slow, initially, and increase with depth into the sediment as a result of increased temperatures. This would lead to a variable gradient and would diminish estimated fluxes to much lower amounts. Finally, for $D_{i}=2.4 \times 10^{-6} \mathrm{~cm}^{2} / \mathrm{sec}$ and a sedimentation rate of $2.5 \mathrm{~cm} / 1000 \mathrm{yr}$, one calculates a $Z^{*}$ of 300 meters, so that, at present, no real steady-state diffusion from the ocean to the levels below 400 meters can be assumed. This will, of course, again reduce the estimated flux.

Careful mass balance considerations of this type may be very important in establishing the nature of the reactions occurring in the sediment column, as far as their rate characteristics are concerned. This again demonstrates that an integrated study of the chemical composition of the interstitial waters, the bulk sediments, and the clay fraction, especially when combined with diffusion considerations, may set limits to when and where diagenetic processes start and occur in the sediment column. This should be checked at many more sites than the ones considered in this chapter.

It is of interest to make a similar analysis of the loss of strontium from the 4-meter-thick nannochalk layer at Site 323. Assuming that steady-state diffusion has existed over a period of $20 \times 10^{6} \mathrm{yr}$, one can calculate (cf., Figure 3) a loss of $730 \mathrm{ppm} \mathrm{Sr}$ from these chalks. No analyses for $\mathrm{Sr}$ in these chalks or the surrounding sediments, except for the clay fraction (Drever, this volume) have been made. We plan to remedy this situation in the near future. From previous data on $\mathrm{Sr}$ in carbonate sediments (Thompson and Bowen, 1969; Warner and Gieskes, 1974), the calculated losses appear somewhat high, however. Again the problem of increased recrystallization upon burial may be a serious one. In addition, the previously suggested possible dissolution of strontium-containing manganese phases may be of importance.

At this stage, it may be concluded that if alteration reactions do indeed occur only in localized portions of the sediment column major compositional changes should be observed in the sediments, unless some severe limitations can be set on the time dependence of reaction rates (increasing upon burial?) and the slopes of the concentration gradients. This problem certainly warrants further careful study.

Of interest with regard to this is the problem of the depletion in $\delta \mathrm{O}^{18}$ in the interstitial waters. As we point out elsewhere in this volume (Lawrence at al.) large depletions in $\delta \mathrm{O}^{18}$ require substantial alteration of sediments and/or underlying basalts. Alteration reactions at Site 323 must have been extensive, but major ion changes can be much smaller because not all the $\mathrm{K}^{+}$and $\mathrm{Mg}^{++}$need to be added from external sources, not does all the $\mathrm{Ca}^{++}$have to be removed. It appears that interstitial water studies must involve studies of $\delta \mathrm{O}^{18}$ to estimate amounts of alteration, whereas chemical gradients indicate what chemical elements are involved in the suggested alteration reactions.

\section{CONCLUSIONS}

Studies of interstitial water composition of sediments retrieved during Leg 35 have revealed the following:

1) Diffusion coefficients can be reliably estimated by means of careful measurements of porosities and socalled formation factors obtained by electrical conductivity measurements. 

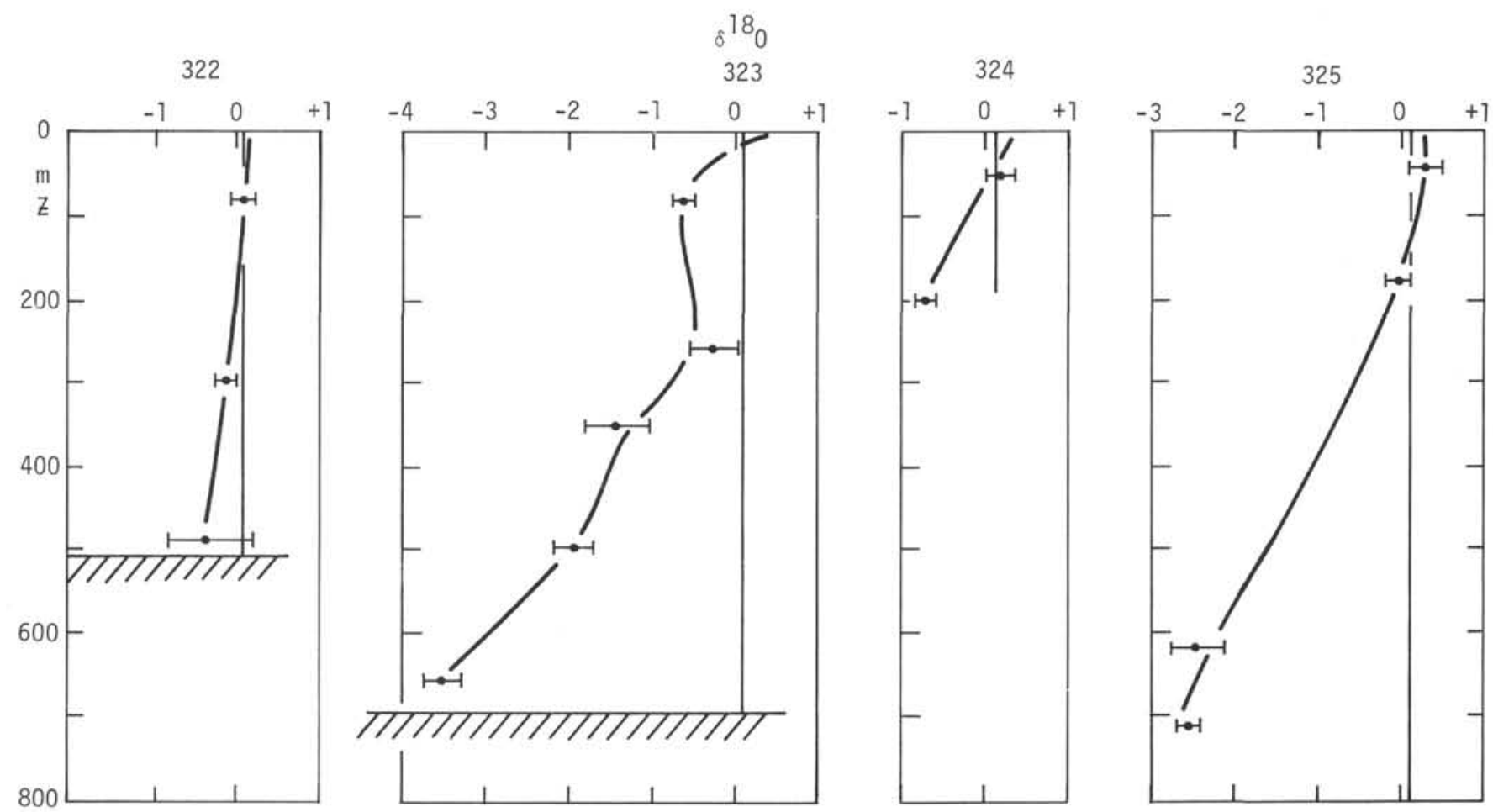

Figure 32. Changes in $\delta 0^{18}$, Sites 322, 323, 324, and 325 .

2) The Antarctic sediments show various identifiable reaction sites involving alteration processes, presumably of land-derived igneous material, volcanic material, and basalts, usually leading to depletions in potassium and magnesium in the interstitial fluids and increases in dissolved calcium.

3) Mass balance considerations based on possible diffusional fluxes suggest that diagenetic reactions may well show a rate dependence with depth of burial which is probably due to downhole temperature increases.

4) Observed concentration changes in the interstitial waters seem to correlate well with observed changes in clay mineralogy and oxygen isotopes in both the sediments and the underlying basalts.

\section{ACKNOWLEDGMENTS}

Many thanks for his conscientious efforts are due the shipboard chemistry technician, Mr. Craig Dootson. This research was generously supported by a special NSF grant, GA-40005, was well as by NSF Grants GA-33229, GA-17724, and DES75-02968.

\section{REFERENCES}

Archie, G.E., 1942. The electrical resistivity log as an aid in determining some reservoir characteristics. AIME Trans., v. 146, p. 54 .

Atkins, E.R. and Smith, G.H., 1961. The significance of particle shape in formation resistivity factor-porosity relationships: J. Petrol. Technol., v. 13, p. 285-291.

Drever, J.I., 1971. Magnesium-iron replacements in clay minerals in anoxic marine sediments: Science, v. 172, p. 1334-1336.

Epstein, S. and Mayeda, T., 1953. Variation in the $\mathrm{O}^{18}$ content of water from natural sources: Geochim. Cosmochim. Acta, v. 4, p. 213.
Gieskes, J.M., 1974. Interstitial water studies, Leg 25. In Simpson, E.S.W., Schlich, R., et al., Initial Reports of the Deep Sea Drilling Project, Volume 25: Washington (U.S. Government Printing Office), p. 361-394.

Gieskes, J.M., 1975. Chemistry of interstitial waters of marine sediments: Ann. Rev. Earth Planet. Sci., v. 3, p. 433-453. , in press. Interstitial water studies, Leg 33. In Jackson, E.D., Schlanger, S.O., et al., Initial Reports of the Deep Sea Drilling Project, Volume 33: Washington (U.S. Government Printing Office).

Gieskes, J.M., Kastner, M., and Warner, T.B.W., 1975. Evidence for extensive diagenesis, Madagascar Basin, Deep Sea Drilling Site 245: Geochim. Cosmochim. Acta. v. 39, p. 1385-1394.

Lawrence, J.R., 1973. Interstitial water studies, Leg 15. Stable oxygen and carbon isotope variations in water, carbonates and silicates from the Venezuela Basin (Site 149) and the Aves Rise (Site 148). In Heezen, B.C., MacGregor, E. D., et al., Initial Reports of the Deep Sea Drilling Project, Volume 20: Washington (U.S. Government Printing Office), p. 891-900.

Lawrence, J.R., Gieskes, J.M., and Broecker, W.S., 1975. Oxygen isotope and cation composition of DSDP pore waters and the alteration of Layer II basalts: Earth Planet. Sci. Lett., v. 27, p. 1-11.

Lerman, A., 1975. Maintenance of steady state in oceanic sediments: Am. J. Sci., v. 275, p. 609-635.

Li, Y-H. and Gregory, S., 1974. Diffusion of ions in sea water and in deep sea sediments: Geochim. Cosmochim. Acta, v. 38 , p. $703-714$.

Manheim, F.T., 1970. The diffusion of ions in unconsolidated sediments: Earth Planet. Sci. Lett. v. 9, p. 307-309.

Manheim, F.T. and Sayles, F.L., 1974. Composition and origin of interstitial waters of marine sediments, based on deep sea drill cores. In Goldberg, E.D. (Ed.), The sea, v. 5: New York (Wiley-Interscience).

Manheim, F.T. and Waterman, L.S., 1974. Diffusimetry (diffusion constant estimation) on sediment cores by resistivity 
probe. In von der Borch, C.C., Sclater, J.G., et al., Initial Reports of the Deep Sea Drilling Project, Volume 22; Washington (U.S. Government Printing Office), p. 663670.

Mann, R. and Gieskes, J.M., 1975. Interstitial water studies, Leg 28. In Hayes, D.E., Frakes, L.A., et al., Initial Reports of the Deep Sea Drilling Project, Volume 28: Washington (U.S. Government Printing Office), p. 805-814.

Perry, E.A., Gieskes, J.M., and Lawrence, J.R., in preparation. Magnesium, calcium, and $\mathrm{O}^{18}$ exchange in the sediment-pore water system, Hole 149 DSDP.

Sayles, F.L. and Manheim, F.T., 1975. Interstitial solutions and diagenesis in deeply buried marine sediments: Results from the Deep Sea Drilling Project: Geochim. Cosmochim. Acta, v. 39, p. 103-127.

Thompson, G. and Bowen, V.T., 1969. Analyses of coccolith ooze from the deep tropical Atlantic: J. Mar. Res., v. 27, p. 32.

Turk, J.T., 1976. A study of diffusion in clay-water systems by chemical and electrical methods. Ph.D. dissertation, University of California, San Diego.

Warner, T.B.W. and Gieskes, J.M., 1974. Iron-rich basal sediments from the Indian Ocean: Site 245, DSDP. In Simpson, E.S.W., Schlich, R., et al., Initial Reports of the Deep Sea Drilling Project, Volume 25: Washington (U.S. Government Printing Office, p. 395-403. 